\title{
Larval fish assemblages in coastal waters of central Greece: reflections of topographic and oceanographic heterogeneity
}

\author{
STYLIANOS SOMARAKIS, STAMATINA ISARI and ATHANASSIOS MACHIAS \\ Hellenic Centre for Marine Research, PO Box 2214, 71003 Heraklion, Crete, Greece. E-mail: somarak@her.hcmr.gr
}

\begin{abstract}
SUMMARY: Patterns in the mesoscale distribution of larval fish in the coastal waters of central Greece, an area of high topographic and bathymetric complexity, were analysed using samples collected during two ichthyoplankton surveys in July 1998 and June 1999. Salinities were lower in the eastern (Aegean) part of the study area due to the influence of waters originating from the Black Sea. In this region, larvae of many epipelagic and benthopelagic (typically summer spawning) species were less abundant in June 1999, when waters were significantly cooler, compared to July 1998. Multivariate analyses identified 'neritic' and 'pelagic' groups of stations dominated by larvae of epipelagic/bethopelagic (typically shelf dwelling) and mesopelagic species. In the west (Ionian Sea), a prominent third group of stations located in the deep and highly enclosed Korinthiakos Gulf was also defined with very high abundances of mesopelagic fish larvae. However, the genera Cyclothone and Vinciguerria that dominated the neighbouring offshore assemblage of the Ionian Sea were absent from this gulf. In the study area, Korinthiakós Gulf ( $>900 \mathrm{~m})$ and North Evoikos ( $>400 \mathrm{~m})$ Gulf comprise unique 'fjord-like' ecosystems in the Mediterranean with increased productivity and significantly cooler deep waters compared to adjacent open sea basins.
\end{abstract}

Keywords: fish larvae, assemblages, spatial distribution, Aegean Sea, Ionian Sea, eastern Mediterranean

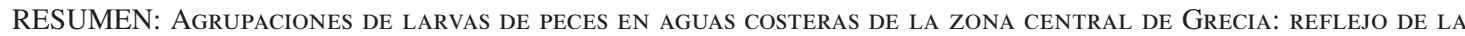
HETEROGENEIDAD EN LA TOPOGRAFÍA Y LA OCEANOGRAFíA. - Se analizaron los patrones de distribución de mesoescala de larvas de peces en aguas costeras de Grecia central (un área de alta complejidad topográfica y batimétrica) mediante el estudio de muestras recogidas en el transcurso de dos muestreos de ictioplancton (julio de 1998 y junio de 1999). En la zona este del área de estudio (mar Egeo), las salinidades fueron menores debido a la influencia de aguas procedentes del mar Negro. En esta región, las larvas de muchas especies epipelágicas y bentopelágicas (normalmente de desove en verano) fueron menos abundantes en junio de 1999, cuando las aguas eran significativamente más frías, en comparación con julio de 1998. Un análisis multivariante identificó los grupos 'nerítico' y 'pelágico' en las estaciones dominadas por larvas de especies epipelágicas/betopelágicas (típicas de plataforma) y mesopelágicas. En el oeste (mar Jónico) se definió un tercer grupo de estaciones con altas abundancias de larvas de peces mesopelágicos ubicadas en el Golfo Korinthiakós, zona muy profunda y cerrada. Sin embargo, los géneros Cyclothone y Vinciguerria, que dominaban en la comunidad de aguas abiertas del Mar Jónico, estaban ausentes en este golfo. Dentro del área de estudio, los golfos de Korinthiakós ( $>900 \mathrm{~m}$ de profundidad) y el del Norte de Evoikos (>400 m) comprenden ecosistemas únicos en el Mediterráneo, semejantes a fiordos, con una productividad elevada y aguas profundas significativamente más frías que las de cuencas adyacentes del mar abierto.

Palabras clave: larva de pez, agrupaciones, distribución espacial, mar Egeo, mar Jónico, Mediterráneo oriental.

\section{INTRODUCTION}

Ichthyoplankton investigations are of unique value for our understanding of reproductive and early life history adaptations of fishes to their ecosystem (Moser and Smith, 1993). In particular, multispecies ichthyoplankton studies can help to improve our knowledge of the reaction of fish populations to physical forcing: inter-specific comparisons of temporal and spatial patterns in larval fish production may provide insights into 
the mechanisms that control reproductive potential and year-class strength (e.g. Frank and Leggett, 1983; Somarakis et al., 2000). The formation of a larval fish assemblage means that component species (often sharing different habitats) synchronize their larval production, which implies that they have similar links with physical and/or trophic variables, similar reproductive and/ or early life history strategies, and probably a similar response to physical forcing and regime shifts (Doyle et al., 2009; Somarakis et al., in press). The integration of ichthyoplankton dynamics and oceanography should therefore underpin any future research on the potential effects of climate change on the distribution and abundance of fish stocks (Keane and Neira, 2008).

In contrast to the western Mediterranean (Sabatés et al., 2007; Olivar et al., 2010) where larval fish assemblage studies have provided a comprehensive view of the link between oceanography and the structure of assemblages, multispecies investigations in the eastern Mediterranean are scant and restricted to the northern Aegean Sea (Somarakis et al., 2000, 2002; Koutrakis et al., 2004; Isari et al., 2008; Tsikliras et al., 2009) and the Sicilian channel (Cuttitta et al., 2004). In this paper, we present the findings of the first mesoscale study on larval fish assemblages that characterize the coastal waters of central Greece during summer (July 1998, June 1999). Our main aim was to define the major distribution and abundance patterns as well as the principal characteristics of the water column that control these patterns.

The coastal waters of the central Aegean and Ionian Seas are characterized by high topographic complexity (Fig. 1). The area includes a series of semi-enclosed gulfs with variable bathymetry $(<120 \mathrm{~m}$ : Patraikos, South Evoikos, Pagasitikos; >400 m: N. Evoikos; and $>900$ m: Korinthiakos Gulf), one relatively open basin with both shelf and deep (>200 m) waters (Saronikos Gulf), and two less enclosed pelagic regions, labelled here as 'Ionian Sea' and 'Aegean Sea' (Fig. 1). Most of the highly enclosed gulfs are inter-connected with natural narrow passages. The Korinthiakos and Saronikos Gulfs are separated by the Isthmus of Korinthos, where there is an artificially-dredged channel ('Korinthos Canal'; 8 km long, $21 \mathrm{~m}$ wide, $8 \mathrm{~m}$ deep); however, there is practically no water exchange between the two gulfs (Lascaratos et al., 1989; Ramfos et al., 2005). To the west, the Korinthiakos Gulf is linked with the Patraikos Gulf through the narrow and shallow-silled Rion Straits $(2 \mathrm{~km}$ wide and $65 \mathrm{~m}$ deep), which in turn is connected to the open Ionian Sea. The Patraikos Gulf is therefore a basin where mixing processes take place between the Ionian Sea and the Korinthiakos Gulf (Friligos et al., 1985).

The major hydrological characteristic of the eastern (Aegean) part of the study area is the influence from less saline (36-37) surface waters of Black Sea origin (BSW) (Poulos et al., 1997). The BSW enters the North Aegean Sea and generally follows a NW cyclonic route. As the BSW ultimately moves south-

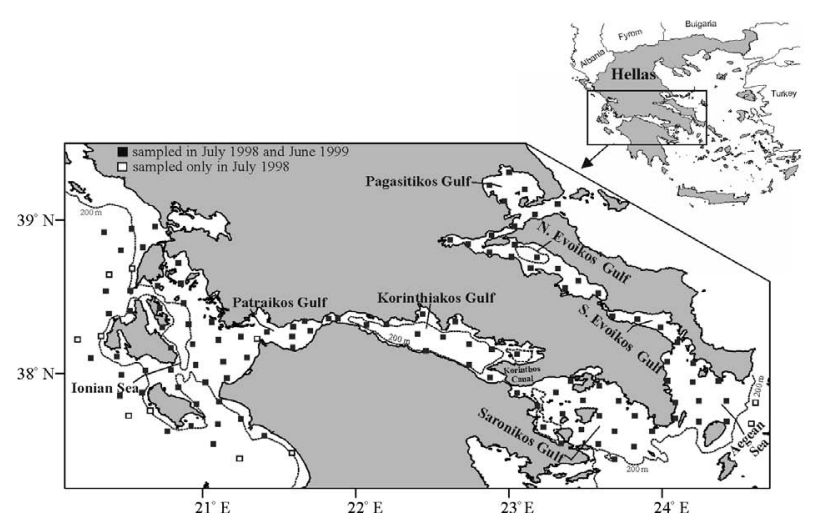

FIG. 1. - Topography of study area and location of sampling stations.

ward along the eastern coast of Greece, it also enters the Pagasitikos and North Evoikos Gulf (Poulos et al., 1997). These gulfs communicate with the open Aegean Sea through a shallow channel system (60-70 m depth). Along its southward movement, the BSW gradually mixes with the more saline (38.5-39.0) surface waters of the Aegean Sea and can even be advected to the South Evoikos and Saronikos Gulfs forming weak haloclines (Poulos et al., 1997). Exchange between the North and South Evoikos Gulf is only possible through a very narrow passage of $10 \mathrm{~m}$ depth.

In contrast to offshore areas of the central Aegean and Ionian Seas, where productivity is comparable to the most oligotrophic areas of the world, the neritic waters of central Greece are relatively more eutrophic (Stergiou et al., 1997; Ramfos et al., 2005), and are inhabited by a diverse assemblage of pelagic and demersal resources that are very important for the traditional fishing activities in Greece (Tzanatos et al., 2005, 2006; Somarakis et al., 2006; Machias et al., 2008). The enclosure of most gulfs is likely to restrict offshore advection of fish larvae with positive consequences for recruitment of local stocks.

\section{MATERIALS AND METHODS}

\section{Sample collection and analysis}

Two oceanographic surveys were carried out in coastal waters of central Greece in July 1998 (6/7-22/7) and June 1999 (30/5-20/6). Sampling was based on an $8 \times 8$ nautical mile grid. A total of 125 stations were sampled in 1998, and 114 stations in 1999 (Fig. 1). Oblique hauls of a $60-\mathrm{cm}$ bongo sampler with mesh sizes of 250 and $500 \mu \mathrm{m}$ in the two nets were performed at these stations. The sampler was towed at 2-2.5 knots from 5 $\mathrm{m}$ from the bottom to the surface or from $200 \mathrm{~m}$ depth to the surface at deep stations. The depth of the sampler was monitored during the tow by means of a depth sensor attached to the sampler that transmitted acoustic signals to an onboard receiver. The volume of water filtered was calculated from a calibrated flow-meter in the mouth of each net. All samples were preserved 

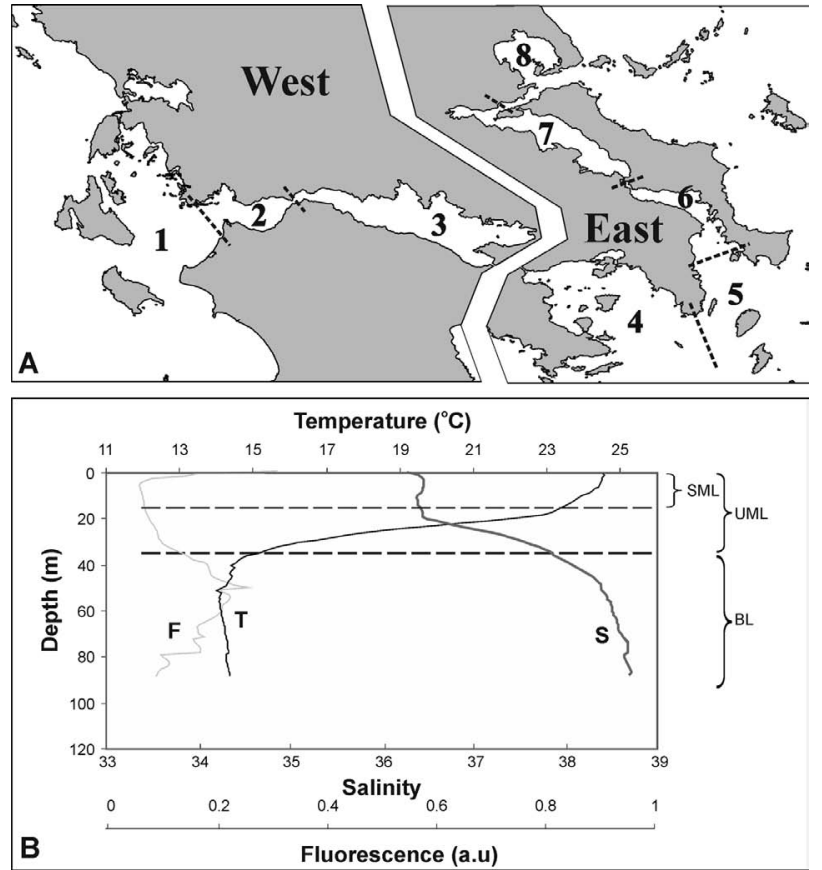

FIG. 2. - (A) Division of the surveyed area into west and east regions. The sub-regions considered in the study are also indicated (1, Ionian Sea; 2, Patraikos Gulf; 3, Korinthiakos Gulf; 4, Saronikos Gulf; 5, Aegean Sea; 6, S. Evoikos Gulf; 7, N. Evoikos Gulf; 8, Pagasitikos Gulf). (B) Example of vertical profiles of temperature, salinity and fluorescence at a station. The different water column layers are indicated: upper mixed layer (UML), surface mixed layer (SML) and bottom layer (BL).

immediately after collection in $10 \%$ borax-buffered formalin. Hydrographic sampling (temperature, salinity and fluorescence profiles of the water column) was also performed at each station using a CTD (SEABIRD SBE-19) equipped with a fluorometer.

Laboratory analysis was restricted to samples collected with the $250 \mu \mathrm{m}$ mesh net. Fish larvae were sorted from the rest of the plankton, identified to the lowest possible taxonomic level, staged into yolk-sac, pre-flexion, flexion and post-flexion larvae and enumerated. The tow-depth and volume of water filtered were used to standardize larval catches to numbers per square metre (Somarakis et al., 1998). The zooplankton displacement volume (ZDV) was measured for each sampling site as a rough estimation of zooplankton production (Somarakis et al., 2002).

\section{Data analysis}

The studied area was divided into two parts, hereafter labelled 'west' (Ionian part) and 'east' (Aegean part) (1998: west; 71 stations, east; 54 stations, 1999: west; 62, east part; 52) (Fig. 2). Exchange between the west and east is trivial and the two regions showed differences in hydrological conditions and species composition. Moreover, eight sub-regions (sbr) with different topographical features were also considered: three in the west (sbr-1: Ionian Sea, sbr-2: Patraikos Gulf, sbr-3: Korinthiakos Gulf) and five in the east (sbr-4: Saronikos Gulf, sbr-5: Aegean Sea, sbr-6: South Evoikos Gulf, sbr-7: North Evoikos Gulf, sbr-8: Pagasitikos Gulf) (Fig. 2).

To examine the spatial patterns of environmental properties, mean values for different parameters (i.e. temperature, salinity, integrated fluorescence) were calculated for three distinct water column layers (Laprise and Pepin, 1995) (Fig. 2B): The layer immediately below the sea-surface down to the depth where the temperature was $1{ }^{\circ} \mathrm{C}$ less than that of the surface waters, was defined as the 'surface mixed layer' (SML). The layer from the surface down to the depth where the temperature was $1{ }^{\circ} \mathrm{C}$ higher than that of the bottom waters, comprised the 'upper mixed layer' (UML). Finally, the layer from the end of the UML down to the bottom, or until $200 \mathrm{~m}$ wherever bottom depth was greater than $200 \mathrm{~m}$, was labelled as 'bottom layer' (BL).

We only considered pre-flexion fish larvae in accordance with the rationale of Isari et al. (2008). The larval fish assemblage structure was analysed using hierarchical, agglomerative average-linkage clustering and non-metric multidimensional scaling (NMDS) (Clarke and Warwick, 1994). Abundance values (numbers $\mathrm{m}^{-2}$ ) of larval taxa were square-root transformed and a sample-to-sample matrix of BrayCurtis similarities was calculated for each area and each individual survey (i.e. West 1998, East 1998, West 1999, East 1999). Prior to ordination, 'outlier' stations identified by the cluster analysis were removed from the data set so that these stations would not bias or dominate the ordination, which often compressed the distribution of the remaining sites (Gauch, 1982; Hosie and Cochran, 1994).

In order to relate assemblage structure to environmental parameters, ordination scores produced by the NMDS were compared by multiple regression analysis with environmental variables to determine which of these parameters best explained the larval fish distributions (Kruskal and Wish, 1978; Hosie and Cochran, 1994). In the regression analysis, the NMDS scores were treated as the independent variables and each environmental parameter as the dependent variable. More details and discussion on the advantages of this method are provided in Somarakis et al. (2002). Regression lines and their directions were superimposed on the MDS plots according to methods described in Kruskal and Wish (1978). The parameters examined were the mean temperature and salinity in the UML and $\mathrm{BL}$, the integrated fluorescence in the UML, the ZDV and haul depth.

Two-way analysis of variance (ANOVA) was applied to test for differences among years and subregions in temperature, salinity and fluorescence of the different water column strata (SML, UML and BL), as well as ZDV, larval abundance and number of larval taxa. For taxa found in both surveys $(1998,1999)$ and regions (west, east) and in 10\% of stations in at least one survey, two-way ANOVA was also performed 

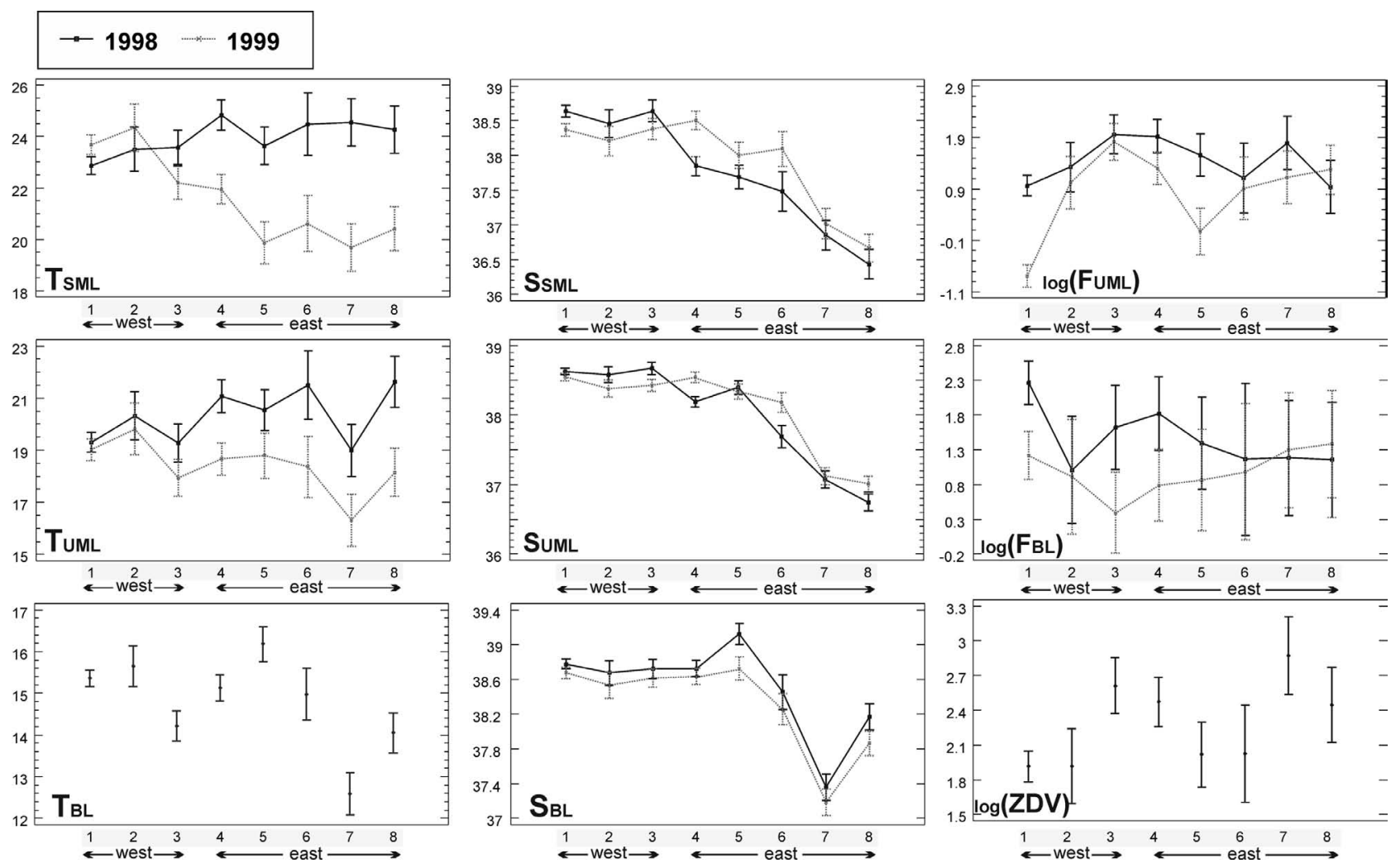

FIG. 3. - Mean values and 95\% Bonferroni-corrected confidence intervals for temperature (T), salinity (S), integrated fluorescence (F) and zooplankton displacement volume (ZDV) for the different depth layers (UML, upper mixed layer; SML, surface mixed layer; BL, bottom layer) and sub-regions (1, Ionian Sea; 2, Patraikos Gulf; 3, Korinthiakos Gulf; 4, Saronikos Gulf; 5, Aegean Sea; 6, S. Evoikos Gulf; 7, N. Evoikos Gulf; 8, Pagasitikos Gulf). The effect of year and the year*sub-region interaction was not significant $(\mathrm{P}>0.05)$ for temperature in the $\mathrm{BL}$ and $\mathrm{ZDV}$.

to test for differences in abundance between west and east and between 1998 and 1999. The ZDV and fluorescence values were transformed $(\log [\mathrm{x}])$ prior to the ANOVA. Larval fish abundances were also transformed to $\log (\mathrm{x}+1)$.

\section{RESULTS}

\section{Environmental conditions}

Strong thermal stratification was observed over the entire study area during both surveys. The mean depth of the thermocline, which was consistently deeper in the sub-regions of Korinthiakos Gulf (sbr3), Saronikos Gulf (sbr-4) and the Aegean Sea (sbr-5), ranged between 19.3 and $41.3 \mathrm{~m}$, with slightly lower values in June 1999.

In July 1998, the mean temperature in the upper water column (UML) ranged between 18.9 and $21.5^{\circ} \mathrm{C}$ with relatively higher values in the east (Fig. 3: sbr- 4, $5,6,8)$. The UML of deeper basins, both in the west and east (i.e. Ionian Sea, Korinthiakos Gulf and N. Evoikos Gulf, sbr-1,3,7), was relatively cooler compared to other sub-regions. Spatial differences in water temperature were less pronounced if the SML (surface mixed layer) was considered (Fig. 3). In June 1999, the mean temperature in the UML was substantially lower than in July 1998 , ranging between 16.3 and $19.8^{\circ} \mathrm{C}$. There were significant between-year differences in temperature, which were stronger for the SML (e.g. a decrease of $5^{\circ} \mathrm{C}$ in sbr-7, N. Evoikos Gulf) than the UML (e.g. a decrease of $3^{\circ} \mathrm{C}$ in sbr-8, Pagasitikos Gulf), particularly in the east (Fig. 3). Sbr-1 and 2 (Ionian Sea and Patraikos Gulf) had slightly higher SML temperatures in June 1999 than in July 1998.

Mean salinity in the upper water column varied considerably both among sub-regions and between surveys (Fig. 3). In the UML, mean salinity exhibited an east-west increasing trend, ranging from 36.6 to 38.8 in July 1998, and from 37 to 38.5 in June 1999. Low salinities and a weak halocline were the main characteristics of the eastern (Aegean) part of the survey during both years, which mainly reflected the influence of Black Sea water (BSW). Pagasitikos (sbr8) and North Evoikos (sbr-7) had the lowest salinity values (particularly in the SML). Relatively low salinities were also detected in the South Evoikos Gulf and Saronikos Gulf (sbr-4, 5, 6), which implies that BSW was also advected in these gulfs (negligible fresh water outflows occur there during summertime, Stergiou et al., 1997). The western part of the surveyed area was relatively homogenous with regard to salinity in the SML and UML, with no statistically significant differences between sub-regions. In June 1999, salinity 
TABLE 1. - Larval fish taxa identified from the surveys of July 1998 and June 1999 . X, mean abundance (larvae $\mathrm{m}^{-2}$ ); \% $\mathrm{N}$, percent of positive stations (frequency of occurrence). Taxa are sorted by type (e, epipelagic; m, mesopelagic; b, benthopelagic). Families in each type are sorted alphabetically.

\begin{tabular}{|c|c|c|c|c|c|c|c|c|c|c|}
\hline \multirow{2}{*}{ Family } & \multirow[b]{2}{*}{ Larval taxon } & \multirow[b]{2}{*}{ Type } & \multicolumn{4}{|c|}{ Western Part } & \multicolumn{4}{|c|}{ Eastern Part } \\
\hline & & & $x^{14}$ & ${ }^{8} \% \mathrm{~N}$ & $x^{19}$ & ${ }^{9} \% \mathrm{~N}$ & & $\% \mathrm{~N}$ & $x^{19}$ & $\% \mathrm{~N}$ \\
\hline Carangidae & Trachurus mediterraneus & $\mathrm{e}$ & 0.99 & 49 & 1.33 & 60 & 2.86 & 74 & 0.96 & 38 \\
\hline & unidentified carangids & $\mathrm{e}$ & - & - & - & - & 0.09 & 2 & - & - \\
\hline Clupeidae & Sardinella aurita & $\mathrm{e}$ & 7.71 & 24 & 2.40 & 29 & 7.34 & 72 & 2.08 & 29 \\
\hline Engraulidae & Engraulis encrasicolus & $\mathrm{e}$ & 27.86 & 97 & 17.34 & 92 & 42.92 & 78 & 9.33 & 94 \\
\hline Scombridae & Auxis rochei & $\mathrm{e}$ & 0.29 & 17 & 0.22 & 24 & 0.45 & 31 & 0.02 & 4 \\
\hline & Euthynnus alletteratus & $\mathrm{e}$ & 0.46 & 17 & 0.01 & 2 & 0.04 & 6 & - & - \\
\hline & Scomber japonicus & $\mathrm{e}$ & 0.16 & 6 & 0.36 & 21 & 0.17 & 11 & 0.04 & 4 \\
\hline Evermannellidae & Evermannella balbo & $\mathrm{m}$ & 0.01 & 1 & - & - & - & - & - & - \\
\hline Gonostomatidae & Cyclothone braueri & $\mathrm{m}$ & 7.13 & 58 & 9.00 & 58 & 0.07 & 13 & 0.15 & 15 \\
\hline & Cyclothone pygmaea & $\mathrm{m}$ & 0.89 & 34 & 0.28 & 27 & - & & 0.01 & 2 \\
\hline Myctophidae & Benthosema glaciale & $\mathrm{m}$ & - & - & 0.05 & 8 & 0.13 & 7 & 0.11 & 6 \\
\hline & Ceratoscopelus maderensis & $\mathrm{m}$ & 15.71 & 79 & 13.41 & 74 & 0.61 & 37 & 1.34 & 33 \\
\hline & Diaphus holti & $\mathrm{m}$ & 0.23 & 21 & 0.29 & 32 & - & - & - & - \\
\hline & Diaphus rafinesquii & $\mathrm{m}$ & 0.01 & 1 & - & - & - & - & - & - \\
\hline & Electrona risso & $\mathrm{m}$ & 0.18 & 15 & 0.07 & 10 & - & - & - & - \\
\hline & Gonichthys cocco & $\mathrm{m}$ & 0.10 & 11 & 0.10 & 15 & 0.01 & 2 & & - \\
\hline & Hygophum benoiti & $\mathrm{m}$ & 8.41 & 75 & 7.56 & 65 & 0.31 & 28 & 0.25 & 12 \\
\hline & Lampanyctus crocodilus & $\mathrm{m}$ & 0.51 & 31 & 0.49 & 40 & 0.01 & 2 & - & - \\
\hline & Lampanyctus pusillus & $\mathrm{m}$ & 0.49 & 28 & 0.19 & 11 & - & - & 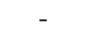 & - \\
\hline & Lobianchia dofleini & $\mathrm{m}$ & 0.02 & 1 & 0.03 & 6 & - & - & 0.01 & 2 \\
\hline & Myctophum punctatum & $\mathrm{m}$ & 0.87 & 41 & 1.93 & 39 & 0.30 & 17 & 0.18 & 6 \\
\hline & Symbolophorus veranyi & $\mathrm{m}$ & 0.03 & 1 & - & - & - & - & - & - \\
\hline Paralepididae & Arctozenus risso & $\mathrm{m}$ & 0.70 & 31 & 0.69 & 35 & - & - & - & - \\
\hline & Lestidiops sp. & $\mathrm{m}$ & 0.21 & 25 & 0.32 & 31 & 0.03 & 6 & 0.02 & 4 \\
\hline Photichthyidae & Ichthyococcus ovatus & $\mathrm{m}$ & 0.01 & 1 & - & - & - & - & - & - \\
\hline & Vinciguerria spp. & $\mathrm{m}$ & 4.31 & 51 & 2.97 & 37 & 0.22 & 17 & 0.06 & 10 \\
\hline Sternoptychidae & Argyropelecus hemigymпиs & $\mathrm{m}$ & 1.01 & 35 & 0.95 & 29 & 0.02 & 4 & & - \\
\hline & Maurolicus muelleri & $\mathrm{m}$ & 3.45 & 44 & 2.56 & 47 & 1.11 & 24 & 5.69 & 33 \\
\hline Stomiidae & Stomias boa boa & $\mathrm{m}$ & 0.01 & 1 & 0.13 & 11 & - & - & - & - \\
\hline Apogonidae & Apogon imberbis & $\mathrm{b}$ & 0.31 & 31 & 0.23 & 23 & 0.43 & 37 & 0.07 & 8 \\
\hline Argentinidae & Glossanodon leioglossus & $\mathrm{b}$ & 0.01 & 1 & 0.03 & 5 & - & - & - & - \\
\hline Blenniidae & unidentified blenniids & $\mathrm{b}$ & 0.08 & 13 & 0.24 & 26 & 0.27 & 35 & 0.47 & 44 \\
\hline & Blennius ocellaris & $\mathrm{b}$ & - & - & 0.01 & 2 & - & - & 0.05 & 8 \\
\hline & Parablennius sanguinolentus & $\mathrm{b}$ & - & - & 0.01 & 2 & - & - & 0.08 & 2 \\
\hline Bothidae & Arnoglossus spp. & b & 0.70 & 52 & 0.98 & 58 & 1.96 & 63 & 1.71 & 71 \\
\hline Bramidae & Brama brama & $\mathrm{b}$ & 0.02 & 3 & 0.01 & 2 & - & - & - & - \\
\hline Callanthiidae & Callanthias ruber & $\mathrm{b}$ & 0.02 & 4 & 0.04 & 8 & 0.02 & 6 & 0.01 & 2 \\
\hline Callionymidae & Callionymus spp. & $\mathrm{b}$ & 0.98 & 46 & 0.84 & 50 & 1.49 & 59 & 1.47 & 69 \\
\hline Caproidae & Capros aper & $\mathrm{b}$ & 0.05 & 3 & 0.02 & 2 & - & - & - & - \\
\hline Carapidae & Carapus sp. & b & - & - & 0.05 & 6 & 0.01 & 2 & - & - \\
\hline Cepolidae & Cepola macrophthalma & $\mathrm{b}$ & 0.90 & 44 & 0.80 & 56 & 1.97 & 56 & 0.94 & 65 \\
\hline Cynoglossidae & Symphurus nigrescens & b & 0.02 & 4 & - & - & - & - & - & - \\
\hline Gadidae & Gadiculus argenteus argenteus & b & - & - & - & - & 0.10 & 7 & 0.24 & 12 \\
\hline Gobiidae & unidentified gobiids & b & 4.33 & 80 & 8.70 & 89 & 7.72 & 96 & 11.70 & 92 \\
\hline & Gobius paganellus & $\mathrm{b}$ & 0.35 & 27 & 0.51 & 37 & 0.72 & 43 & 0.48 & 37 \\
\hline Labridae & Coris julis & $\mathrm{b}$ & 0.83 & 51 & 2.89 & 81 & 0.85 & 44 & 0.92 & 35 \\
\hline & unidentified labrids & $\mathrm{b}$ & 0.21 & 17 & 0.66 & 40 & 0.16 & 22 & 0.81 & 56 \\
\hline Lophiidae & Lophius budegassa & $\mathrm{b}$ & - & - & - & - & - & - & 0.01 & 2 \\
\hline Macrouridae & unidentified macrourids & b & 0.06 & 8 & 0.13 & 15 & 0.01 & 2 & - & - \\
\hline Merlucciidae & Merluccius merluccius & $\mathrm{b}$ & 0.00 & - & 0.01 & 2 & 0.01 & 2 & 0.03 & 4 \\
\hline Mugilidae & Liza spp. & b & 0.17 & 17 & 0.07 & 10 & 0.28 & 24 & 0.01 & 2 \\
\hline Mullidae & Mullus spp. & $\mathrm{b}$ & 0.26 & 25 & 0.40 & 35 & 0.19 & 19 & 0.12 & 12 \\
\hline Ophichthidae & unidentified ophichthiids & b & 0.03 & 6 & 0.03 & 3 & 0.01 & 2 & - & - \\
\hline Ophidiidae & Parophidion vassali & $\mathrm{b}$ & 0.11 & 14 & 0.14 & 19 & 0.02 & 4 & 0.02 & 4 \\
\hline Pomacentridae & Chromis chromis & $\mathrm{b}$ & 6.15 & 89 & 3.76 & 76 & 4.47 & 78 & 3.56 & 42 \\
\hline Scorpaenidae & Scorpaena spp. & $\mathrm{b}$ & 0.27 & 31 & 0.09 & 18 & 0.11 & 22 & - & - \\
\hline Serranidae & Anthias anthias & $\mathrm{b}$ & 0.12 & 17 & 0.02 & 3 & 0.16 & 19 & - & - \\
\hline & Epinephelus sp. & b & 0.04 & 7 & - & - & - & - & 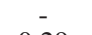 & - \\
\hline & Serranus cabrilla & $\mathrm{b}$ & 0.65 & 49 & 1.40 & 69 & 0.45 & 37 & 0.29 & 37 \\
\hline & Serranus hepatus & b & 1.16 & 55 & 3.32 & 77 & 6.76 & 80 & 2.82 & 77 \\
\hline Soleidae & Buglossidium luteum & b & - & - & & - & - & - & 0.52 & 21 \\
\hline & Microchirus variegatus & $\mathrm{b}$ & 0.01 & 1 & 0.05 & 6 & 0.02 & 4 & 0.06 & 10 \\
\hline Sparidae/ & Boops boops & b & - & - & 0.02 & 5 & - & - & - & - \\
\hline Centracanthidae & Dentex dentex & $\mathrm{b}$ & - & - & 0.07 & 8 & - & - & - & - \\
\hline & Pagellus erythrinus & $\mathrm{b}$ & 0.50 & 48 & 1.34 & 60 & 1.20 & 65 & 0.43 & 40 \\
\hline & unidentified sparids/centracanthic & is b & 0.35 & 27 & 1.72 & 63 & 3.01 & 80 & 12.66 & 96 \\
\hline Sygnathidae & Unidentified sygnathids & $\mathrm{b}$ & 0.01 & 1 & 0.01 & 2 & 0.01 & 2 & & \\
\hline & Hipросатрus sp. & $\mathrm{b}$ & - & - & - & - & 0.01 & 2 & 0.01 & 2 \\
\hline Synodontidae & Synodus saurus & b & - & - & - & - & 0.03 & 4 & - & - \\
\hline Trachinidae & Trachinus draco & $\mathrm{b}$ & 0.01 & 1 & 0.01 & 2 & 0.02 & 2 & - & - \\
\hline Trachinidae & Trachinus vipera & $\mathrm{b}$ & 0.01 & 1 & - & - & - & - & - & - \\
\hline Trichiuridae & Lepidopus caudatus & $\mathrm{b}$ & 0.06 & 7 & 0.05 & 10 & 0.11 & 15 & 0.11 & 10 \\
\hline Triglidae & Lepidotrigla cavillone & $\mathrm{b}$ & 0.06 & 6 & 0.11 & 19 & 0.04 & 7 & 0.06 & 13 \\
\hline Uranoscopidae & Uranoscopus scaber & $\mathrm{b}$ & - & - & 0.01 & 3 & 0.02 & 2 & - & - \\
\hline Distroyed/uniden & ied larvae & & 4.47 & 87 & 8.31 & 95 & 12.38 & 91 & 10.05 & 94 \\
\hline
\end{tabular}


was higher in the east, which implies that the BSW had a low influence in that year. Inter-annual differences were statistically significant only for the Saronikos and S. Evoikos Gulfs (sbr-4, 6). In the west, salinity was slightly higher in 1999.

Contrary to observed inter-annual differences in the physical properties of the UML, the bottom layer (BL) was relatively stable with no significant interannual differences, at least in mean temperature. The BL was generally colder (range among sub-regions, 1998: 12.8$16.2^{\circ} \mathrm{C}$; 1999: $12.4-16.1^{\circ} \mathrm{C}$ ) and more saline (1998: 37.4-39.1; 1999: 37.2-38.7) than the UML. The BL of Korinthiakos and N. Evoikos Gulfs (sbr-3, 7) was significantly cooler. In addition, the latter sub-region (sbr-7) had a remarkably low temperature $\left(<12^{\circ} \mathrm{C}\right)$ and salinity $(<38)$ compared to the neighbouring gulfs.

The integrated fluorescence in the UML was lower in the pelagic areas of the Ionian and Aegean Seas (sbr-1, 5), especially in June 1999 (Fig. 3). The Korinthiakos, Saronikos and N. Evoikos Gulfs (sbr-3, 4, 7) had slightly higher values. When the BL was considered, the Ionian and Aegean Seas (sbr-1, 5) had higher values, which can be attributed to deep fluorescence maxima at offshore sites, located at about $80 \mathrm{~m}$ depth (fluorescence maxima were located at 40-60 $\mathrm{m}$ in other sub-regions). Fluorescence in the BL was higher in sub-regions with deep (>200 m) sampling sites (sbr 1, 3, 4, 5) in July 1998 (mid-summer) than in June 1999 (early summer), which indicates that deep chlorophyll maxima become better established later in the season. There were no statistically significant differences in the ZDV between years. In the western (Ionian) region, the Korinthiakos Gulf (sbr-3) exhibited higher zooplankton concentrations (Fig. 3). In the east, N. Evoikos (sbr-7) and to a lesser extent Saronikos Gulf (sbr-4) had relatively higher ZDVs compared to the other sub-regions.

\section{Fish larvae composition and abundance}

A total of 74 larval taxa were identified (56 at the species, 10 at the genus, and 7 at the family level) in the plankton collections of both surveys (1998: 67, 1999: 64). The number of recorded taxa was generally higher in the west (1998: 60, 1999: 61) than in the east (1998: 51, 1999: 43) (Table 1). The mean number of taxa in sampling stations was relatively higher in the pelagic waters of the Ionian (sbr-1) and Aegean Seas (sbr-5), but also in the Korinthiakos Gulf (sbr 3). The number of taxa was relatively lower in the cooler waters of the east during June 1999 (Fig. 4).

Larvae of six epipelagic, typically summer spawning species (e.g. Engraulis encarsicolus, Sardinella aurita, Trachurus mediterraneus, scombridae), constituted an important component of the larval fish assemblage in terms of abundance and frequency of occurrence (Table 1). The abundance of these species ranged between 4 and $591 \mathrm{~m}^{-2}$ in 1998 , exhibiting the highest values at coastal sites in both the west (i.e. Patraikos Gulf, sbr-2) and the
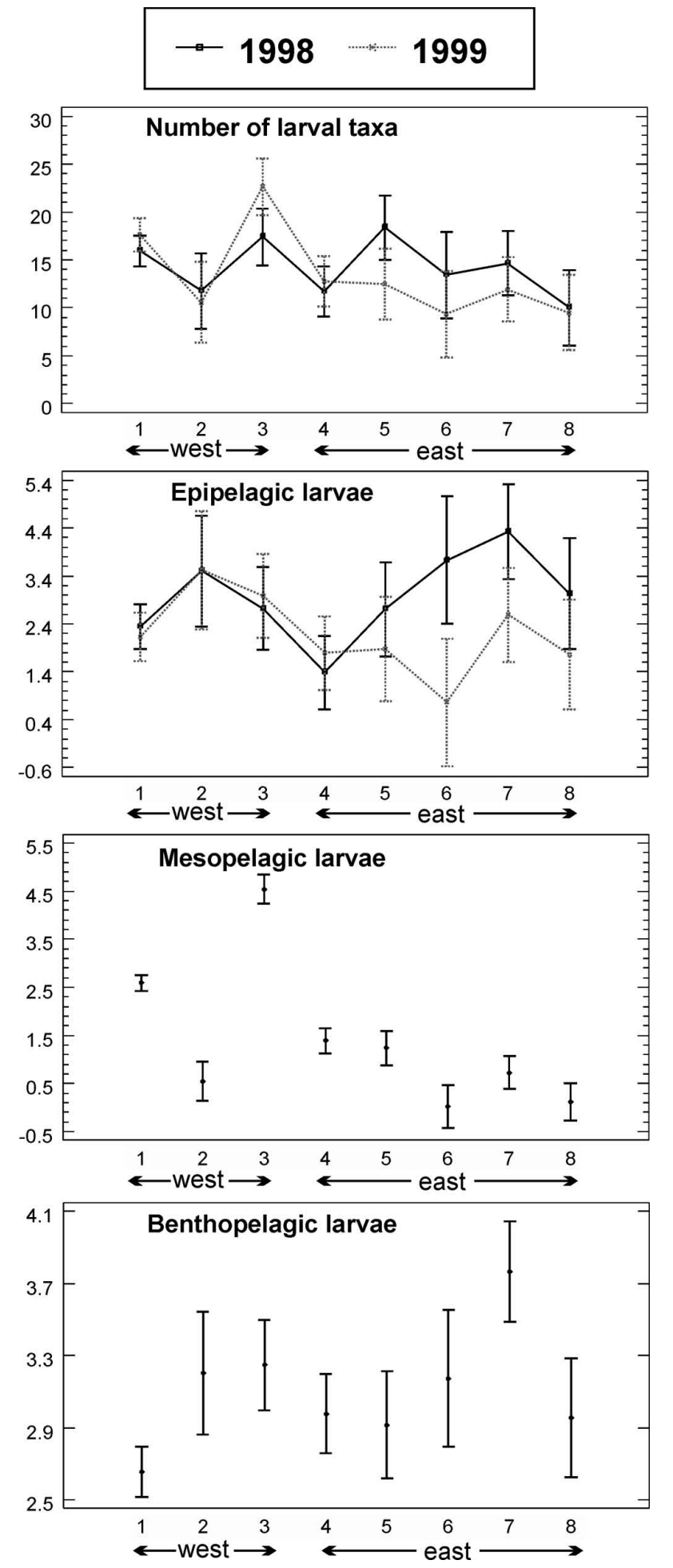

FIG. 4. - Mean values and 95\% Bonferroni-corrected confidence intervals per sub-region and survey for the number of larval taxa as well as for the $\log (\mathrm{x}+1)$-transformed larval abundance (ind $\left.\mathrm{m}^{-2}\right)$ of different fish types (epipelagic, mesopelagic, benthopelagic species). 1, Ionian Sea; 2, Patraikos Gulf; 3, Korinthiakos Gulf; 4, Saronikos Gulf; 5, Aegean Sea; 6, S. Evoikos Gulf; 7, N. Evoikos Gulf; 8, Pagasitikos Gulf. The effect of year and the year*subregion interaction was not significant $(\mathrm{P}>0.05)$ for mesopelagic and benthopelagic species. 
1998
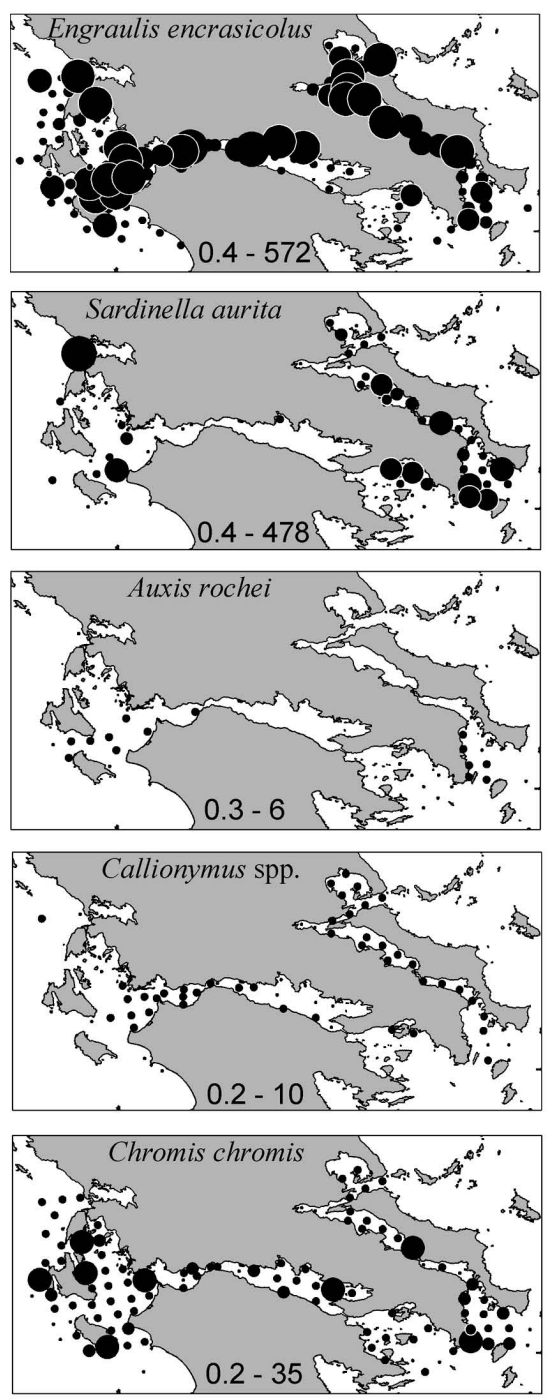

1999
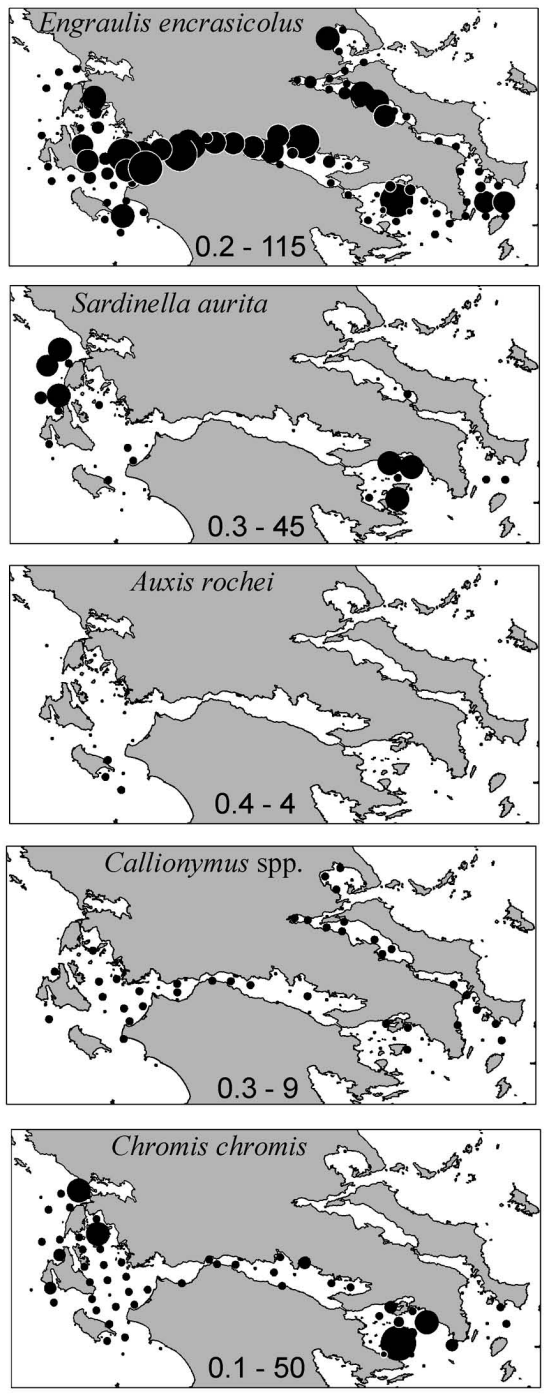
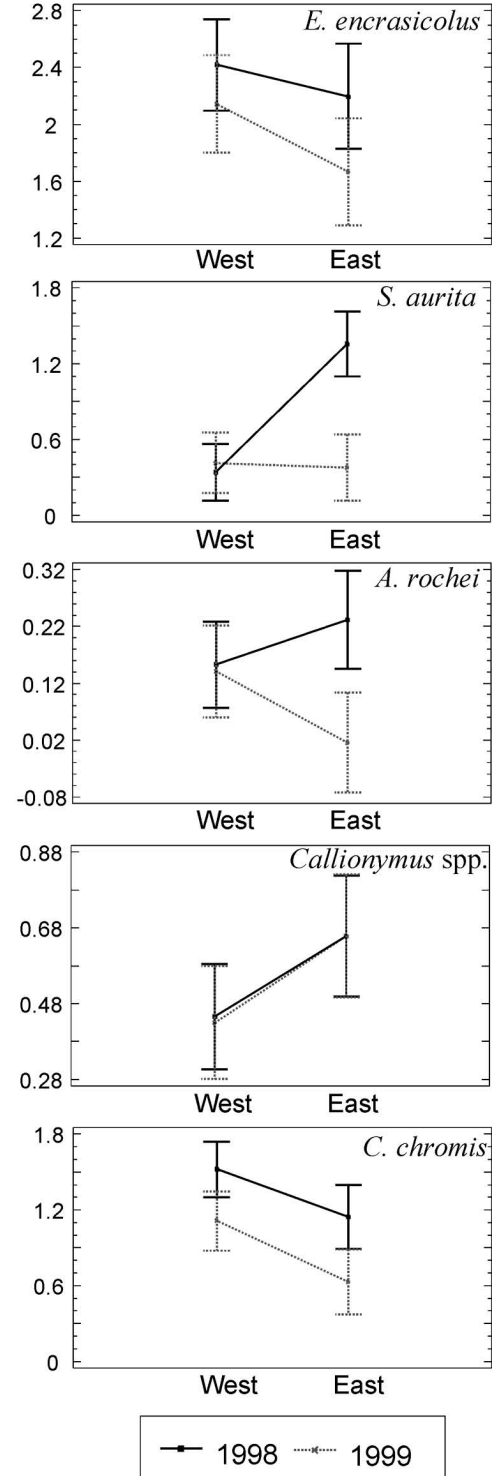

FIG. 5. - Distribution and abundance of larvae (ind $\mathrm{m}^{-2}$ ) of selected taxa during the two surveys. The range for abundance values (positive stations) is given in each map. Interaction plots (region $\times$ survey) for $\log (\mathrm{x}+1)$-transformed abundance (ind $\left.\mathrm{m}^{-2}\right)$ are also given (right panel) with $95 \%$ Bonferroni-corrected confidence intervals.

east (i.e. N. Evoikos Gulf, sbr-7) (Fig. 4). In June 1999, epipelagic species were recorded in significantly lower numbers $\left(0.2-120 \mathrm{~m}^{-2}\right)$, particularly in the east (sbr 5-8) (Fig. 4). This decrease in abundance of epipelagic fish larvae was also evident at the species level (Fig. 5). For instance, larvae of E. encrasicolus, the most abundant and frequently occurring species in both surveys, were caught in lower numbers in the east during June 1999. Other, relatively abundant epipelagic species, such as $S$. aurita (Fig. 5), T. mediterraneus and Auxis rochei (Fig. 5 ), occurred in significantly higher concentrations in the east during July 1998.

Twenty-two larval taxa belonged to the mesopelagic species (Table 1). The total abundance of mesopelagic larvae (1998: 0.3-331 m-2; 1999: 0.3-196 m-2) showed no significant interannual variation (Table 1, Fig. 4). Their horizontal distribution was heterogeneous with particularly high concentrations in the sub-regions of the Korinthiakos Gulf (sbr-3) and the Ionian Sea (sbr1) (Fig. 4). Despite this general pattern, taxa differed in terms of numerical abundance and distribution in the different sub-regions. Based on these two criteria, seven distributional patterns (labelled I-VII) could be distinguished (Fig. 6A). These are exemplified by characteristic species-specific distribution maps for July 1998 in Figure 6B. Strong spatiotemporal variation in the composition of the mesopelagic larval assemblage was revealed (Fig. 6C). 
A

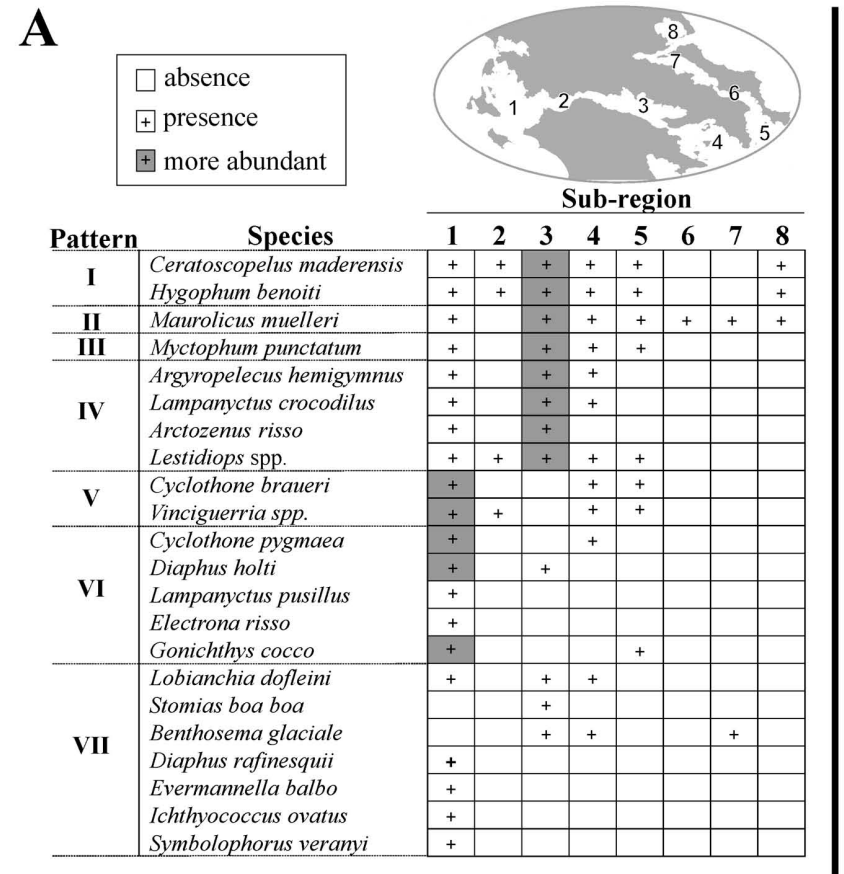

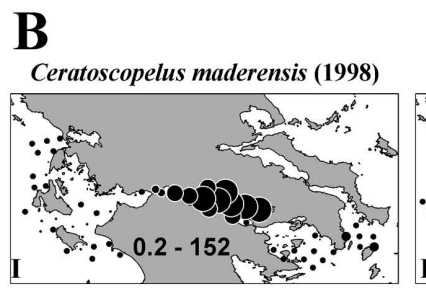
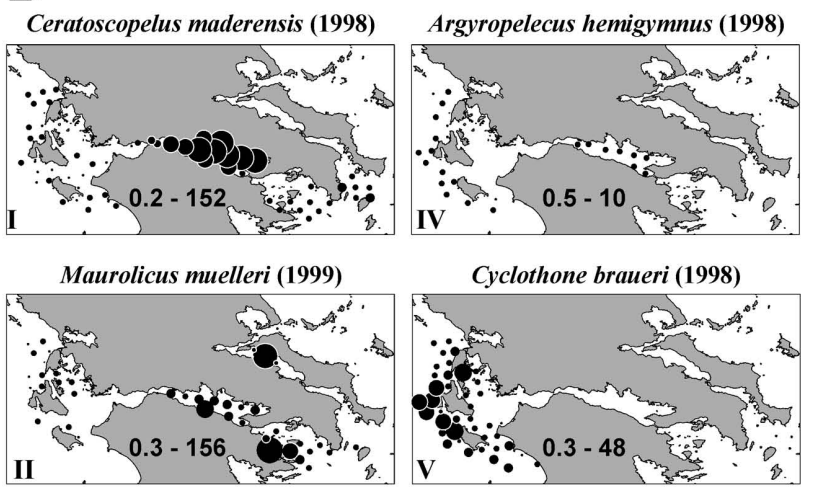

Cyclothone braueri (1998)

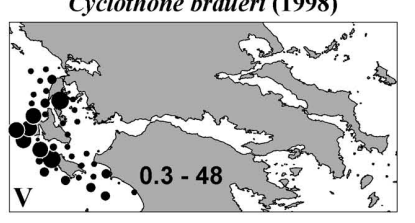

Myctophum punctatum (1998)

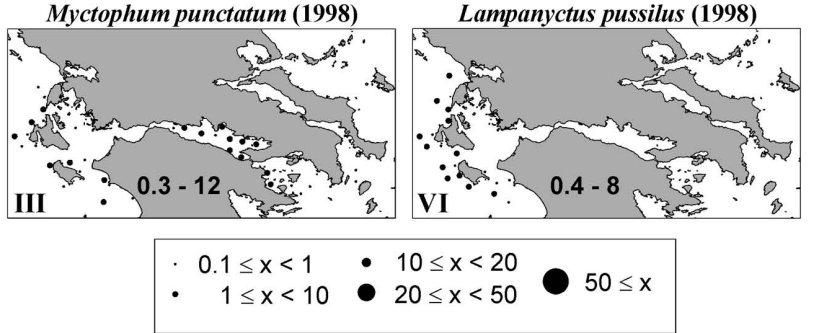

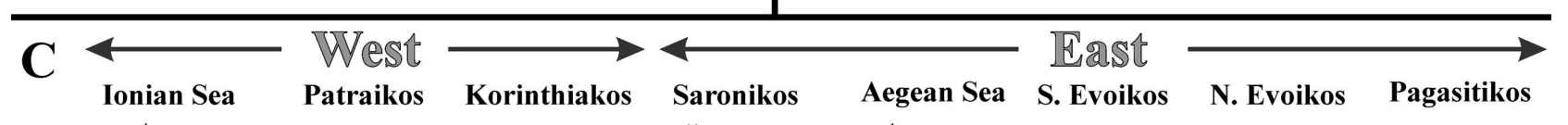
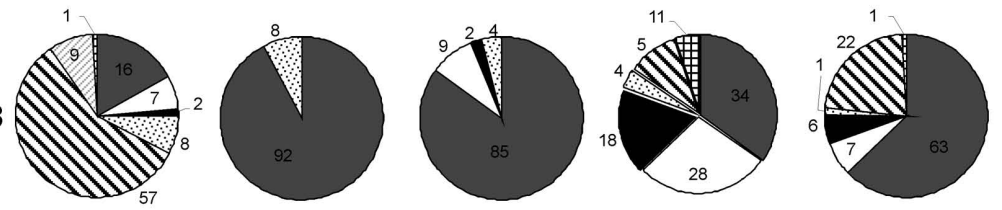

no larvae
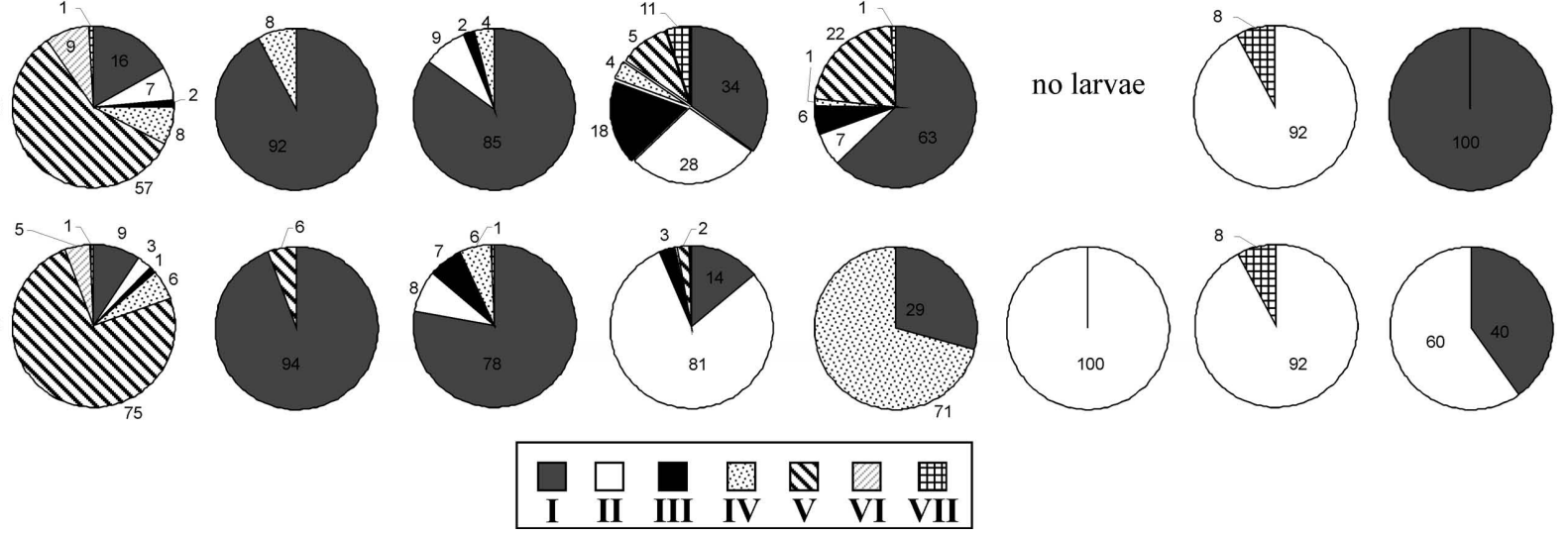

FIG. 6. - Larvae of mesopelagic species. (A) Distribution patterns (I-VII) exhibited by the mesopelagic taxa in both surveys. The taxa were assigned to patterns on the basis of their presence and relative abundance in each sub-region. (B) Distribution and abundance of larvae (ind $\mathrm{m}^{-2}$ ) of selected taxa in 1998 exemplifying distribution patterns I-VI. The respective range of abundance values (positive stations) is given in each map. (C) The percentage contribution to the mesopelagic assemblage structure of taxa with distribution patterns I-VII in each sub-region and year.

The most abundant species, namely the myctophids Ceratoscopelus maderensis and Hygophum benoiti, had almost identical distributions (Pattern I). They were caught in substantial numbers in both coastal and pelagic waters during both surveys (Fig. 6A). They were remarkably abundant in Korinthiakos Gulf (sbr 3) (Fig. $6 \mathrm{~A}, \mathrm{~B})$, and dominated the assemblage of this subregion (Fig. 6C). Larvae of Maurolicus muelleri and Myctophum punctatum (following in rank order of abundance) were assigned to different distribution patterns (II and III). The species M. muelleri had an extended presence all over the study area (except in Patraikos Gulf, sbr-2) (Fig. 6A) with high abundances in Korin- thiakos Gulf (Fig. 6B). It also occurred at deeper stations of Saronikos Gulf (sbr-4) and N. Evoikos Gulf (sbr-7), contributing greatly to local mesopelagic assemblages (Fig. 6C). Myctophum punctatum presented lower densities and a limited presence at coastal sites (sbr 2, 6, 7, 8) and was mainly collected in the Korinthiakos Gulf (sbr-3) and pelagic waters of the Ionian Sea (sbr-1) (Fig. 6A, B). Higher concentrations in the Korinthiakos Gulf were also observed for four additional taxa. Due to their lower densities and increased presence in the Ionian Sea, they were assigned to another pattern (pattern IV).

A unique pattern (pattern V) was exhibited by larvae of Cyclothone braueri and Vinciguerria spp. 
They were particularly abundant in offshore waters of the west (Table 1) and dominated the mesopelagic assemblage of the Ionian Sea (sbr-1) (Fig. 6A, B, C). Several other species also showed a preference for offshore waters in the Ionian Sea; however, these were recorded in low numbers (pattern VI). The remaining taxa listed in Figure 6A had a sporadic presence either in the Ionian Sea or in other sub-regions (pattern VII). The Korintiakos Gulf (sbr-3), Ionian Sea (sbr-1) and Evoikos Gulf (sbr-7) showed the least inter-annual variation in relative composition of species patterns (Fig. 6C), which suggests that local mesopelagic assemblages were basically endogenous, i.e. less affected by advection of larvae from other areas.

Forty-five larval taxa belonged to benthopelagic fishes (Table 1). Their total abundance ranged from 0.9 to $110 \mathrm{~m}^{-2}$ in 1998 and from 0.4 to $333 \mathrm{~m}^{-2}$ in 1999 . Along the study area, N. Evoikos (sbr-7) presented the highest concentrations of benthopelagics, whereas the Ionian Sea (sbr-1) had the lowest (Fig. 4). Speciesspecific distribution patterns revealed differences in space and time, mainly related to topographic features and temperature regimes. In general, larvae of the families Gobiidae and Sparidae (most of which were not possible to identify to the species level) were the most abundant and frequent during both surveys. Both families were broadly distributed over the entire sampling area, with particularly high densities in the east. Callionymus spp. (Fig. 5), Arnoglossus spp., Serranus hepatus and Cepola rubescens had distributions that were more restricted to the shelf $(<200 \mathrm{~m})$ and were also particularly abundant in the east. Some species, such as Chromis chromis (Fig. 5), Apogon imperbis, Lisa spp. and Scorpaena spp., exhibited lower concentrations in the east during June 1999, similarly to epipelagic species. Other species, i.e. Coris julis and Serranus cabrilla, were more abundant in the west during June 1999.

\section{Larval assemblage structure in the west (sub-regions 1, 2, 3)}

Cluster analysis applied to larval assemblage data for the western part of the surveyed area defined three main groups of stations (Fig. 7) at a similarity level of about $37 \%$ in both years (groups $\mathrm{W}_{\mathrm{I}}, \mathrm{W}_{\mathrm{II}}, \mathrm{W}_{\mathrm{III}}$ ). Sampling sites situated in the Korinthiakos Gulf (subregion 5) formed a highly differentiated group (group $\mathrm{W}_{\mathrm{I}}$ ) that remained almost unchanged between surveys. Mesopelagic species with distribution patterns I and II (i.e. Ceratoscopelus maderensis, Hygophum benoiti, Maurolicus muelleri) contributed in shaping the assemblage structure of group $\mathrm{W}_{\mathrm{I}}$. Samples collected from the adjacent waters of Patraikos Gulf as well as from the inner part of the Ionian Sea (mostly shelf stations) were grouped together (group $\mathrm{W}_{\mathrm{II}}$ ), and showed a distinct assemblage structure mainly dominated by larvae of the epipelagic species Engraulis encrasicolus and Sardinella aurita as well as the
1998

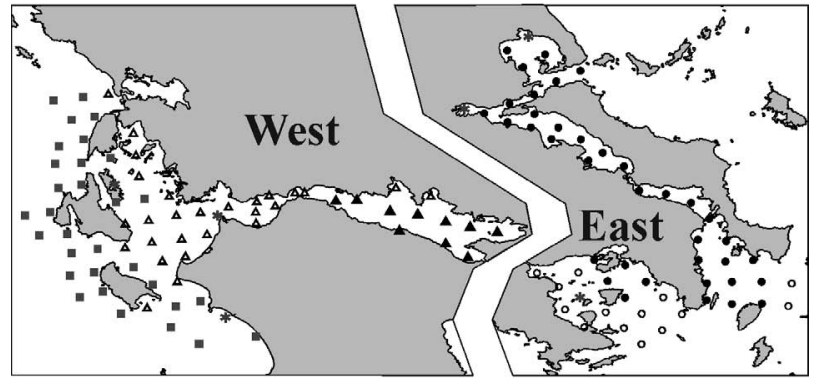

1999

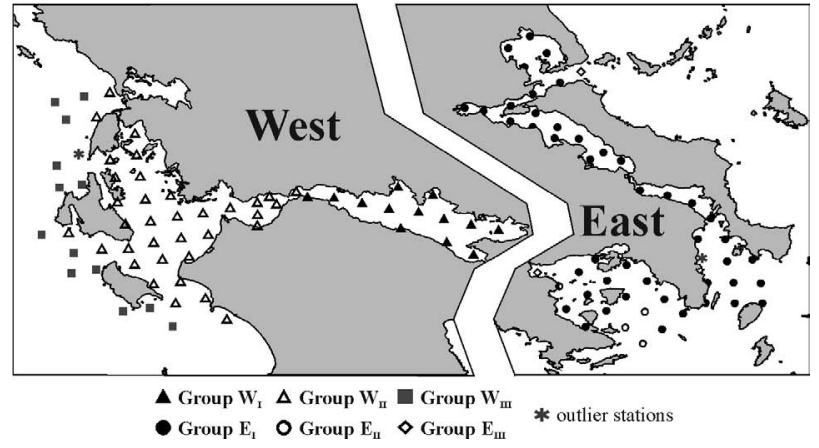

FIG. 7. - Maps showing station groups defined by the cluster analyses.

benthopelagics Serranus hepatus, gobiids, Callionymus spp. and Chromis chromis. This grouping was extended towards offshore waters of the Ionian Sea in June 1999 compared to July 1998. The outer stations of the Ionian Sea formed group $\mathrm{W}_{\mathrm{III}}$, which exhibited lower total larval abundances as well a strong contribution of mesopelagics with pattern V (Cyclothone braueri and Vinciguerria spp.). During 1998, three coastal sites were clustered as outliers because of the generally low total abundance values for fish larvae and low number of taxa compared to adjacent stations (Fig. 7). In 1999, only one station was an outlier, mainly due to its low number of mesopelagic species and the overall low abundance of fish larvae.

The NMDS ordinations (excluding outlier stations) showed that the station groups identified by the cluster analysis were distinct (Fig. 8). Haul depth, ZDV and integrated fluorescence in the UML were significantly and strongly related to ordination scores in both years (Table 2). The relative angles of intersection suggest that the ZDV and integrated fluorescence (UML) were related to the differentiation of group $\mathrm{W}_{\mathrm{I}}$ (Korinthiakos Gulf was richer in zooplankton and had high fluorescence, Table 3). Haul depth mainly explained the differentiation of group $\mathrm{W}_{\mathrm{II}}$ (shallower stations of Patraikos Gulf and the inner Ionian Sea) from groups $\mathrm{W}_{\mathrm{I}}$ and $\mathrm{W}_{\mathrm{III}}$ (deeper sites, Table 3 ). Lower temperatures (in the UML and/or BL) were also related to the differentiation of the Korinthiakos Gulf assemblage (group $\mathrm{W}_{\mathrm{I}}$ ) (Fig. 8). Significant relationships with salinity (upper and/or bottom layer) differentiated group $\mathrm{W}_{\text {III }}$ (higher salinity in the outer Ionian Sea, Table 3). 

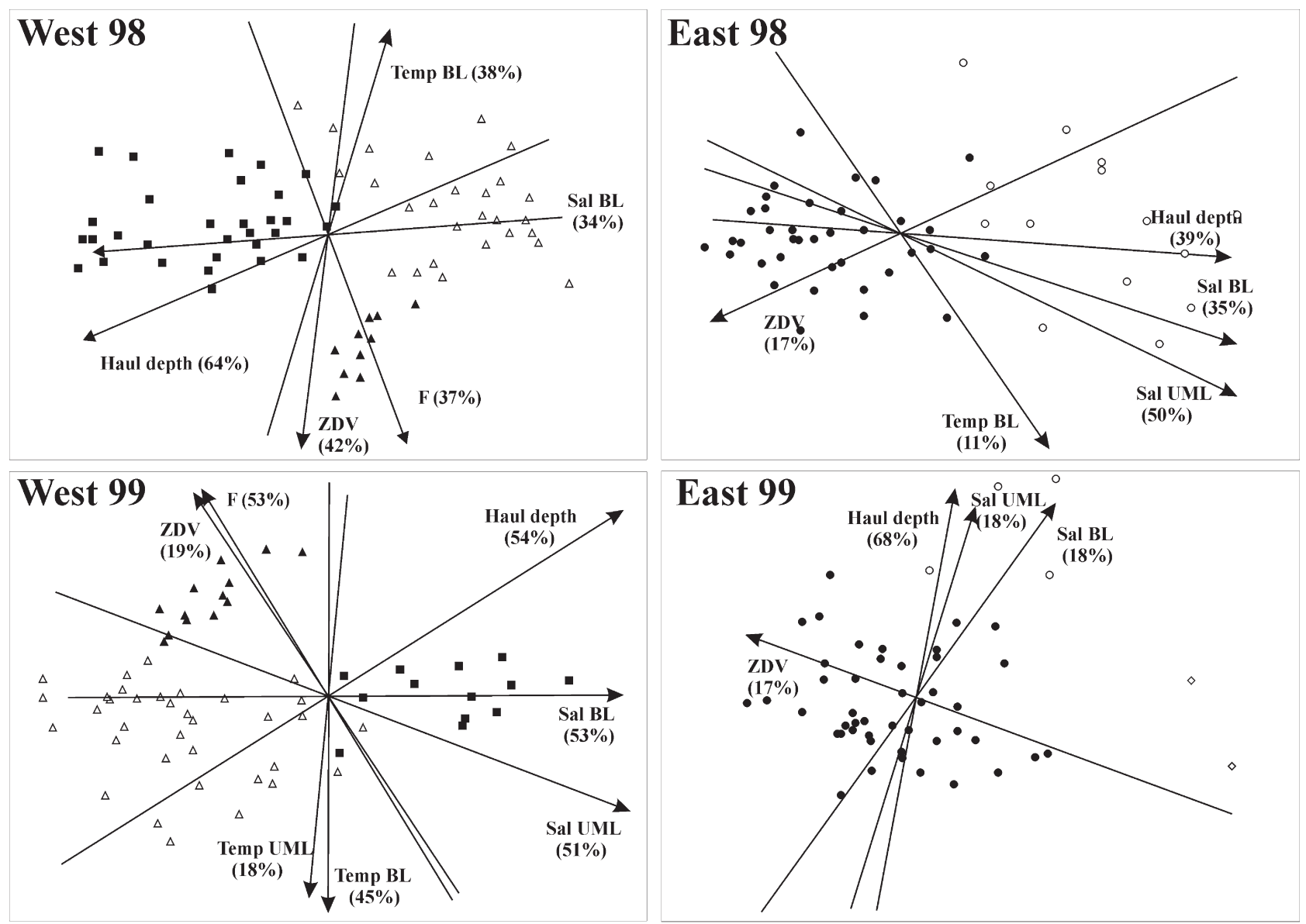

$\Delta$ Group $_{\text {I }} \Delta$ Group $W_{\text {II }}$ Group $W_{\text {III }}$

- Group $E_{1} \bigcirc$ Group $E_{\mathrm{II}} \diamond$ Group $E_{\mathrm{III}}$

FIG. 8. - NMDS ordination plots of the comparison of sampling sites. The respective station groups defined by cluster analysis are indicated. Significant multiple regressions between ordination scores and the examined parameters are superimposed together with the fraction (\%) of variance explained in each regression (Sal: salinity, Temp: temperature, F: integrated fluorescence, ZDV: zooplankton displacement volume, UML upper mixed layer. BL: bottom layer).

TABLE 2. - Multiple regression analysis between environmental parameters and the non-metric multidimensional scaling (NMDS) scores for two-axis ordination of sampling sites ( $\mathrm{X}, \mathrm{Y}$ : direction cosines) ( ${ }^{*}, \mathrm{P}<0.05 ;{ }^{* *}, \mathrm{P}<0.01$; ***, $\mathrm{P}<0.001$; n.s., not significant).

\begin{tabular}{|c|c|c|c|c|c|c|c|}
\hline \multirow{6}{*}{$\begin{array}{l}\text { West98 } \\
\text { X } \\
\text { Y } \\
\text { Adj. } \text { R }^{2} \\
\text { F }\end{array}$} & \multicolumn{2}{|c|}{ Temperature $\left({ }^{\circ} \mathrm{C}\right)$} & \multicolumn{2}{|c|}{ Salinity } & \multirow{2}{*}{$\begin{array}{c}\text { Fluorescence } \\
\text { UML }\end{array}$} & \multirow{2}{*}{$\begin{array}{c}\mathrm{ZDV} \\
\left(\mathrm{ml} \mathrm{m}^{-2}\right)\end{array}$} & \multirow{2}{*}{$\begin{array}{l}\text { Haul Depth } \\
\text { (m) }\end{array}$} \\
\hline & UML & $\mathrm{BL}$ & UML & BL & & & \\
\hline & & 0.208 & & -0.995 & 0.256 & -0.088 & -0.854 \\
\hline & & 0.978 & & -0.104 & -0.967 & -0.996 & -0.520 \\
\hline & & 37.7 & & 33.9 & 36.6 & 41.9 & 64.3 \\
\hline & $1.07^{\text {n.s. }}$ & $20.98^{\text {*** }}$ & $1.86^{\text {n.s. }}$ & $17.91^{* * *}$ & $19.8^{* * * *}$ & $25.15^{* * *}$ & $61.28^{* * *}$ \\
\hline \multicolumn{8}{|l|}{ East 98} \\
\hline $\mathrm{X}$ & & 0.435 & 0.824 & 0.905 & & -0.834 & 0.995 \\
\hline $\mathrm{Y}$ & & -0.900 & -0.566 & -0.425 & & -0.552 & -0.102 \\
\hline Adj. $R^{2}$ & & 11.0 & 50.0 & 35.3 & & 16.6 & 39.1 \\
\hline $\mathrm{F}$ & $0.01^{\text {n.s. }}$ & $3.77^{*}$ & $23.49^{* * *}$ & $13.27^{* * *}$ & $1.77^{\text {n.s. }}$ & $5.97^{* *}$ & $17.04^{* * *}$ \\
\hline \multicolumn{8}{|l|}{ West 99} \\
\hline $\mathrm{X}$ & -0.065 & 0.005 & 0.877 & 1.000 & -0.391 & -0.381 & 0.741 \\
\hline $\mathrm{Y}$ & -0.998 & -1.000 & -0.480 & 0.006 & 0.920 & 0.924 & 0.671 \\
\hline Adj. $R^{2}$ & 18.4 & 45.0 & 50.9 & 53.0 & 52.5 & 18.9 & 53.6 \\
\hline $\mathrm{F}$ & $7.75^{* *}$ & $25.26^{\text {*** }}$ & $32.14^{* * *}$ & $34.82^{* * *}$ & $33.67^{* * *}$ & $8^{* * *}$ & $36.05^{* * *}$ \\
\hline \multicolumn{8}{|l|}{ East 99} \\
\hline$X$ & & & 0.136 & 0.394 & & -0.935 & 0.099 \\
\hline Y & & & 0.991 & 0.919 & & 0.354 & 0.995 \\
\hline Adj. $R^{2}$ & & & 18.0 & 18.2 & & 16.5 & 68.4 \\
\hline $\mathrm{F}$ & $0.54^{\text {n.s. }}$ & $0.68^{\text {n.s. }}$ & $24.75^{* * * *}$ & $22.29^{* * *}$ & $0.21^{\text {n.s. }}$ & $5.94^{* *}$ & $55.16^{* * * *}$ \\
\hline
\end{tabular}


TABLE 3. - Mean values for temperature $\left(\mathrm{T},{ }^{\circ} \mathrm{C}\right)$, salinity $(\mathrm{S})$, integrated fluorescence $(\mathrm{F})$, haul depth $(\mathrm{m})$ and zooplankton displacement volume $\left(\mathrm{ZDV}, \mathrm{ml} \mathrm{m}^{-2}\right)$ for the station groups defined by the cluster analysis. N, number of stations; UML, upper mixed layer; BL, bottom layer.

\begin{tabular}{|c|c|c|c|c|c|c|c|c|c|}
\hline & & $\mathrm{W}_{\mathrm{I}}$ & $\mathrm{W}_{\mathrm{II}}$ & $\mathrm{W}_{\mathrm{III}}$ & & & $\mathrm{E}_{\mathrm{I}}$ & $\mathrm{E}_{\mathrm{II}}$ & $\mathrm{E}_{\mathrm{III}}$ \\
\hline West 1998 & $\begin{array}{l}\text { T (UML) } \\
\text { T (BL) } \\
\text { S (UML) } \\
\text { S (BL) } \\
\text { F (UML) } \\
\text { ZDV } \\
\text { Haul Depth } \\
\text { N }\end{array}$ & $\begin{array}{c}19.1 \\
13.9 \\
38.7 \\
38.7 \\
7.9 \\
16.8 \\
164.7 \\
10\end{array}$ & $\begin{array}{c}19.7 \\
15.4 \\
38.6 \\
38.7 \\
3.8 \\
7.1 \\
73.6 \\
27\end{array}$ & $\begin{array}{c}19.2 \\
15.1 \\
38.6 \\
38.8 \\
2.8 \\
8.3 \\
170.9 \\
31\end{array}$ & East 1998 & $\begin{array}{l}\text { T (UML) } \\
\text { T (BL) } \\
\text { S (UML) } \\
\text { S (BL) } \\
\text { F (UML) } \\
\text { ZDV } \\
\text { Haul Depth } \\
\text { N }\end{array}$ & $\begin{array}{c}20.9 \\
14.9 \\
37.6 \\
38.4 \\
5.0 \\
11.6 \\
74.3 \\
37\end{array}$ & $\begin{array}{c}20.4 \\
15.0 \\
38.3 \\
38.8 \\
7.2 \\
8.8 \\
148.6 \\
14\end{array}$ & \\
\hline West 1999 & $\begin{array}{l}\text { T (UML) } \\
\text { T (BL) } \\
\text { S (UML) } \\
\text { S (BL) } \\
\text { F (UML) } \\
\text { ZDV } \\
\text { Haul Depth } \\
\text { N }\end{array}$ & $\begin{array}{c}17.8 \\
14.1 \\
38.4 \\
38.6 \\
6.8 \\
14.0 \\
152.7 \\
13\end{array}$ & $\begin{array}{c}19.3 \\
15.6 \\
38.5 \\
38.6 \\
1.4 \\
9.2 \\
85.5 \\
35\end{array}$ & $\begin{array}{c}18.9 \\
15.2 \\
38.6 \\
38.7 \\
0.5 \\
8.8 \\
182.2 \\
13\end{array}$ & East 1999 & $\begin{array}{l}\text { T (UML) } \\
\text { T (BL) } \\
\text { S (UML) } \\
\text { S (BL) } \\
\text { F (UML) } \\
\text { ZDV } \\
\text { Haul Depth } \\
\text { N }\end{array}$ & $\begin{array}{c}18.1 \\
14.5 \\
37.9 \\
38.2 \\
3.6 \\
13.7 \\
77.1 \\
45\end{array}$ & $\begin{array}{c}18.4 \\
14.8 \\
38.6 \\
38.7 \\
4.5 \\
12.9 \\
180.5 \\
4\end{array}$ & $\begin{array}{c}18.3 \\
14.0 \\
37.7 \\
38.4 \\
6.1 \\
12.6 \\
103.5 \\
2\end{array}$ \\
\hline
\end{tabular}

\section{Larval assemblage structure in the east} (sub-regions: $4,5,6,7,8$ )

During July 1998, cluster analysis defined two main groups of stations at a similarity level of $28 \%$ (groups $\mathrm{E}_{\mathrm{I}}$ and $\left.\mathrm{E}_{\mathrm{II}}\right)$ (Fig. 7). Group $\mathrm{E}_{\mathrm{I}}$ comprised the majority of sites located in sub-regions 5, 6, 7, 8 as well as inshore sites in the Saronikos Gulf (sbr-4). The southwestern and deeper part of the Saronikos Gulf together with the two outermost stations in the Aegean Sea formed a separate group (group $\mathrm{E}_{\mathrm{II}}$ ) which was mainly distinguished by the low abundances of small pelagics ( $E$. encrasicolus, $S$. aurita) and benthopelagic taxa (e.g. gobiids, $C$. chromis, $S$. hepatus) and the high concentrations of mesopelagic taxa (e.g. C. maderensis, $M$. mиelleri). Three coastal stations displayed notable difference in assemblage structure: one site in Pagasitikos Gulf (dominated by larvae of the genus Callionymus and gobiids) and two sites in the N. Evoikos and Saronikos Gulf (characterized by a low number of species and rather low abundances).

A slight interannual variability characterized station grouping in the east. In June 1999, the spatial distribution of group $\mathrm{E}_{\mathrm{I}}$ was more expanded and comprised almost all stations except certain relatively deeper sites in Saronikos Gulf (Group $\mathrm{E}_{\mathrm{II}}$ ), which had a higher contribution of mesopelagic (e.g. M. muelleri, C. maderensis) and a lower contribution of epipelagic species (e.g. E. encrasicolus). Moreover, two coastal sites, with low numbers of species and dominated by E. encrasicolus, formed a distinct third group (group $\mathrm{E}_{\mathrm{III}}$ ). Finally, a single coastal site was designated as an outlier due to a high concentration of Callionymus spp.

The NMDS ordinations showed that the two main station groups identified by the cluster analysis were distinct (Fig. 8). The environmental parameters that were significantly related to the ordination scores are shown in Table 2. Salinity (in UML, BL) and haul depth were the most significant factors in both years. The ZDV and bottom layer temperature were also significant (the latter only in 1998). Haul depth and salin- ity were associated with the differentiation of group $E_{I}$ from $\mathrm{E}_{\mathrm{II}}$ (shallower sites with lower salinity, especially in the north versus deeper sites in the south, Table 3) (Fig. 8). In both surveys, the ZDV mainly distinguished group $\mathrm{E}_{\mathrm{I}}$, which had higher values, especially in Evoikos Gulf (Table 3).

\section{DISCUSSION}

The coastal waters of central Greece are heterogeneous in terms of enclosure and bathymetry (Giannoulaki et al., 2003). In particular, the Korinthiakos Gulf in the west and the Evoikos Gulf in the east comprise unique 'fjord like' ecosystems with depths $>900$ and $>450 \mathrm{~m}$ respectively.

At the peak of the last glacial period the sea level in the Aegean and Ionian Seas dropped by about 120 $\mathrm{m}$ and the deeper basins of Korinthiakos and Evoikos Gulf became isolated lakes (palaeolakes) with no exchange with the open sea. Recent geological studies indicate that these palaeolakes became hyper-saline (Karageorgis et al., 2006), which implies the likely extirpation of local fish stocks. At about $11000 \mathrm{yr}$ BP, exchange between the Korinthiakos and N. Evoikos Gulfs and open sea was re-established (Stergiou et al., 1997). This isolation of the Korinthiakos Gulf from the Ionian Sea during the last glacial period could explain the relatively fewer species of mesopelagic fish found in this gulf. Of particular interest is the absence of the genera Cyclothone and Vinciguerria from Korintiakos Gulf, which is characteristic species of the neighbouring Ionian Sea. According to Badcock and Merrett (1976) adults of these genera are 'non-migrants', i.e. they do not migrate to the euphotic zone at night, as do most mesopelagic species. This might be a reason for the absence of these genera from Korinthiakos Gulf, i.e. they did not successfully colonize Korinthiakos Gulf (through the shallow Patraikos Gulf) after the last glacial period or even before. Alternatively, these (and possibly other mesopelagic species that were not captured in Korinthiakos Gulf) may require deeper waters 
than the about $900 \mathrm{~m}$ waters in the gulf to complete their life cycle. Only two mesopelagic species (Maurolicus muelleri and Benthosema glaciale) were collected in the N. Evoikos Gulf (with a maximum depth of about $450 \mathrm{~m}$ ). This could also be explained with similar arguments. In shallower gulfs in the east, like the Pagasitikos and South Evoikos (depth $<102 \mathrm{~m}$ ), the presence of mesopelagic fish larvae was sporadic and most probably the result of larval advection from deeper basins.

The deeper waters of the Korinthiakos and $\mathrm{N}$. Evoikos Gulfs (especially the later) had significantly cooler bottom waters (BL) in comparison with offshore sites of the Ionian and the Aegean Seas (Fig. 3). It seems likely that deep layers of these basins are less affected by the general trend of increasing water temperatures in the Mediterranean, even in deep waters (Lejeusne et al., 2009), and confirms their relative isolation. Larvae of the gadoid Gadiculus argenteus argenteus were consistently caught at deep (>200 m) sites of the N. Evoikos Gulf during both years. This species is known to spawn during winter in the Mediterranean (Motos Izeta, 1985) and seems therefore to also reproduce during summer in the N. Evoikos Gulf.

The 1999 survey was carried out earlier in the season (June) than the 1998 survey (July). Thermal stratification was therefore less advanced in 1999, as evidenced by shallower UML depths and lower UML and SML temperatures, particularly in the east (the first leg of the survey). When compared to July 1998, the mean number of taxa per sampling site was lower in the cooler waters of the east during June 1999. The abundance of epipelagic taxa (especially those of Sardinella aurita, Trachurus mediterraneus, Auxis rochei and, to a lesser extent, Engraulis encrasicolus) was also lower. The same was true for larvae of the benthopelagics, e.g. Chromis chromis, Lisa spp., Apogon imperbis, Scorpaena spp., Trachinus draco and Anthias anthias.

Similarly, in early summer (June) surveys over the North Aegean Sea continental shelf (Somarakis et al., 2000), larvae of S. aurita, T. mediterraneus, A. rochei and certain typically 'summer spawning' benthopelagic species (Sabatés, 1990) like Chromis chromis and Lisa saliens were more abundant and occurred more frequently in years with warmer sea waters. In the Mediterranean, the period of spring-early summer is a transitional period in the reproduction of fish species (Sabatés and Maso 1992; Sabatés and Olivar, 1996). It marks the end of the spawning season of those species that reproduce during winter and the start for summer spawners (Tsikliras et al., 2010). The lower abundance and frequency of occurrence of certain epipelagic and benthopelagic taxa in the west during June 1999 could therefore be attributed to the delayed start of spawning, i.e. higher temperature thresholds to initiate spawning in these typically summer spawning species (Somarakis et al., in press).

The eastern part of the region, particularly the $\mathrm{Pa}$ gasitikos and the North Evoikos Gulfs, had lower sa- linities due to the presence of waters originating from the Black Sea (BSW) (Poulos et al., 1997; Ramfos et $a l ., 2005)$. The BSW, especially when it is less mixed with the Aegean Sea water (i.e. it is less saline), is rich in organic matter and is known to enhance local productivity (Isari et al., 2006, 2007). This might explain the relatively higher zooplankton concentrations recorded in the Pagasitikos and N. Evoikos Gulfs compared to southern areas (Fig. 3). The influence (or mixing) of BSW followed a north-south gradient as evidenced by decreasing values of salinities between the northern and southern part of the study area. Furthermore, in 1999, waters were less saline in the east compared to 1998 , which indicates that the influence of BSW might have been lower during that year. In the North Aegean Sea, the extension of anchovy larval grounds is clearly related to the horizontal distribution of BSW (Isari et al., 2008). Moreover, higher egg and larval production has been reported in years with lower salinities (Somarakis and Nikolioudakis, 2007; Somarakis et al., in press). The inter-annual difference in salinity observed in this study could therefore explain (at least in part) the low abundance of anchovy in the east during June 1999.

Most broad-scale ichthyoplankton studies on continental shelves around the world (Somarakis et al., 2002) have identified two main depth-related larval fish assemblages, i.e. shelf and offshore assemblages, with the greatest contrast being roughly between the two sides of the shelf break (at about $200 \mathrm{~m}$ ). This pattern was also evident in this study particularly in the western (Ionian) region where the sampling grid extended far beyond the continental shelf (i.e. many more offshore stations were sampled in the west). Haul depth was closely related to the ordination scores in both areas and years (Fig. 8), which reflects this onshore-to-offshore transition and membership of the assemblages. With the exception of Korinthiakos Gulf, two main groups of stations were identified in both years and areas corresponding to: (a) primarily shelf stations and a high contribution of epipelagic and benthopelagic, typically shelf dwelling, species; and (b) offshore sites dominated by mesopelagic fish larvae. In both areas, the shelf group was more expanded during June 1999 than in July 1998. A combination of factors, such as narrow continental shelves, absence of shelf-slope fronts (e.g. Sabatés and Olivar, 1996) and increased offshore dispersion of shelf-spawned larvae at lower temperatures (due to higher stage durations of early stages), can explain this wider offshore extension of the shelf group (Somarakis et al., 2002).

The most peculiar group of stations in both years was the one in Korinthiakos Gulf. Its differentiation was clearly associated with increased productivity (fluorescence and ZDV) (Fig. 8, Table 3). Fresh water runoff from surrounding mountains and wind induced upwelling along the NW coasts (Laskaratos et al., 1989) of this gulf have been reported to enhance its productivity. Examination of hydrographic profiles re- 
vealed the presence of weak upwelling in the NW part of the gulf during both years (Ramfos et al., 2005). The abundances of mesopelagic taxa, especially the species Ceratoscopelus maderensis and Hygophum benoiti were particularly high in Korinthiakos Gulf and this could be attributed to the high zooplankton abundance. Similar associations of larvae of Myctophidae with increased plankton production have also been reported in the N. Aegean Sea (Somarakis and Maraveya, 2001; Somarakis et al., in press) and off the U.S. northwest coast (Doyle et al., 1993). In the former, the association was interpreted in terms of higher reproductive effort in zooplankton rich waters (Somarakis et al., in press).

The complex topographic and oceanographic features of the coastal waters of central Greece (in terms of bathymetry, degree of land enclosure, water column properties and local productivity) were reflected in the distribution and abundance patterns of fish larvae. The assemblage was differentiated into pelagic and neritic components with mesopelagic species playing a major role in determining the structure, composition and distribution of assemblages. More detailed studies including sampling at different scales (fine and mesosampling) in both the horizontal and vertical planes, and taking into account variables related to larval prey availability and current fields (e.g. Olivar et al., 2010) will help to better understand the agents (other than adult spawning location and intensity) that shape the larval fish assemblages in this area.

\section{ACKNOWLEDGEMENTS}

We would like to thank Eleni Maraveya and Cryssa Tsimenides for their assistance in laboratory analysis and identification of ichthyoplankton. Dr Marianna Giannoulaki is particularly thanked for her help in the analysis of hydrographic data. The contribution of Professor Constantin Koutsikopoulos in designing and executing sampling cruises is much appreciated. Finally, members of the laboratories of the former Institute of Marine Biology of Crete (IMBC) and the Biology Department of the University of Patras are thanked for their assistance during the surveys. This study was partly supported by the European project 'Evaluation of the southern Greek anchovy stocks'- DG XIV, Project no. 97-0048.

\section{REFERENCES}

Badcock, J. and N.R. Merrett. - 1976. Midwater fishes in the eastern North Atlantic - I. Vertical distribution and associated biology in $30^{\circ} \mathrm{N}, 23^{\circ} \mathrm{W}$, with developmental notes on certain myctophids. Prog. Oceanogr., 7: 3-58.

Clarke, K.R. and R.M. Warwick. - 1994. Change in Marine Communities: an Approach to Statistical Analysis and Interpretation. Natural Environment Research Council, UK, 144 pp.

Cuttitta, A., A. Arigo, G. Basilone, A. Bonanno, G. Buscaino, L. Rollandi, J. Garcia Lafuente, A. Garcia, S. Mazzola and B Patti. -2004 . Mesopelagic fish larvae species in the Strait of Sicily and their relationships to main oceanographic events. Hydrobiologia, 527: 177-182.

Doyle, M.J., W.W. Morse and A.W.Jr. Kendall. - 1993. A com- parison of larval fish assemblages in the temperate zone of the northeast Pacific and northwest Atlantic oceans. Bull. Mar. Sci., 53: 588-644.

Doyle, M.J., S.J. Picquelle, K.L. Mier, M.C. Spillane and N.A. Bond. - 2009. Larval fish abundance and physical forcing in the Gulf of Alaska, 1981-2003. Prog. Oceanogr., 80: 163-187.

Frank, K.T. and W.C. Leggett. - 1983. Multispecies larval fish associations: accident or adaptation? Can. J. Fish. Aquat. Sci., 40: 754-762.

Friligos, N., A. Theocharis and D. Georgopoulos. - 1985. Preliminary chemical and physical observations during summer 1980 on a silled embayment in the Ionian Sea. Vie Milieu, 35: $115-125$.

Gauch, Jr.H.G. - 1982. Multivariate Analysis in Community Ecology. Cambridge University Press, Cambridge, 298 pp.

Giannoulaki, M., A. Machias, C. Koutsikopoulos, J. Haralabous, S. Somarakis and N. Tsimenides. - 2003. Effect of coastal topography on the spatial structure of the populations of small pelagic fish. Mar. Ecol. Prog. Ser., 265: 243-253.

Hosie, G.W. and T.G. Cochran. - 1994. Mesoscale distribution patterns of macrozooplankton communities in Prydz bay, Antarctica - January to February 1991. Mar. Ecol. Prog. Ser., 106: 21-39.

Isari, S., A. Ramfos, S. Somarakis, C. Koutsikopoulos, A. Kallianiotis and N. Fragopoulu. - 2006. Mesozooplankton distribution in relation to hydrology of the Northeastern Aegean Sea (eastern Mediterranean). J. Plankton Res., 28: 241-255.

Isari, S., S. Psarra, P. Pitta, P. Mara, M.O. Tomprou, A. Ramfos, S. Somarakis, A. Tselepides, C. Koutsikopoulos and N. Fragopoulu. - 2007. Differential patterns of mesozooplankters' distribution in relation to physical and biological variables of the northeastern Aegean Sea (eastern Mediterranean). Mar. Biol., 151: 1035-1050.

Isari, S., N. Fragopoulu and S. Somarakis. - 2008. Interannual variability in horizontal patterns of larval fish assemblages in the northeastern Aegean Sea (eastern Mediterranean) during early summer. Estuar. Coast. Shelf. Sci., 79: 607-619.

Karageorgis, A.P., C. Anagnostou, T. Kanellopoulos and R.O. Hallberg. - 2006. Carbonate mineral deposits in Hellenic plaeolakes during the last glacial period. Proceeding of the $8^{\text {th }}$ Panhellenic Symposium of Oceanography and Fisheries, pp. 801-805.

Keane, J.P. and F.J. Neira. - 2008. Larval fish assemblages along the south-eastern Australian shelf: linking mesoscale non-depthdiscriminate structure and water masses. Fish. Oceanogr., 17: 263-280.

Koutrakis, E.T., A.A Kallianiotis and A.C. Tsikliras. - 2004. Temporal patterns of larval fish distribution and abundance in a coastal area of northern Greece. Sci. Mar., 68: 585-595.

Kruskal, J.B. and M. Wish. - 1978. Multidimensional scaling. Sage Publications, Beverly Hills.

Laprise, R. and P. Pepin. - 1995. Factors influencing the spatiotemporal occurrence of fish eggs and larvae in a northern, physically dynamic coastal environment. Mar. Ecol. Prog. Ser., 122: 73-92.

Lascaratos, A., E. Salusti and G. Papageorgaki. - 1989. Wind-induced upwellings and currents in the Gulfs of Patras, Nafpaktos and Korinthos, western Greece. Oceanol. Acta, 12: 159-164.

Lejeusne, C., P. Chevaldonne, C. Pergent-Martini, C.F. Boudouresque and T. Perez. - 2009. Climate change effects on a miniature ocean: the highly diverse, highly impacted Mediterranean Sea. Trends Ecol. Evol., 25: 250-260.

Machias, A., K.I. Stergiou, S. Somarakis, V.S. Karpouzi and A. Kapantagakis. -2008 . Trends in trawl and purse seine catch rates in the north-eastern Mediterranean. Medit. Mar. Sci., 9: 49-65.

Moser, H.G. and P.E. Smith. - 1993. Larval fish assemblages and oceanic boundaries. Bull. Mar. Sci., 53: 283-289.

Motos Izeta, L. - 1985. The larval development of the southern silvery pout Gadiculus argenteus argenteus Guichenot (1850). J. Plankton Res., 7: 937-946.

Olivar, M.P., M. Emelianov, F. Villate, I. Uriarte, F. Maynou, I. Alvarez and E. Morote. - 2010. The role of oceanographic conditions and plankton availability in larval fish assemblages off the Catalan coast (NW Maditerranean). Fish. Oceanogr., 19: 209-229.

Poulos, S.E., P.G. Drakopoulos and M.B. Collins. - 1997. Seasonal variability in sea surface oceanographic conditions in the Aegean Sea (Eastern Mediterranean): an overview. J. Mar. Syst., 13: 225-244. 
Ramfos, A., S. Somarakis, C. Koutsikopoulos and N. Fragopoulu. 2005. Summer mesozooplankton distribution in coastal waters of central Greece (eastern Mediterranean). I. Hydrology and group composition. J. Mar. Biol. Assoc. U.K., 85: 755-764.

Sabatés, A. - 1990. Distribution pattern of larval fish populations in the Northwestern Mediterranean. Mar. Ecol. Prog. Ser., 59: 75-82.

Sabatés, A. and M. Maso. - 1992. Unusual larval fish distribution pattern in a coastal zone of the western Mediterranean. Limnol. Oceanogr., 37: 1252-1260.

Sabatés, A. and M. P. Olivar. - 1996. Variation of larval fish distributions associated with variability in the location of a shelfslope front. Mar. Ecol. Prog. Ser., 135: 11-20.

Sabatés, A., M.P. Olivar, J. Salat, I. Palomera and F. Alemany. 2007. Physical and biological processes controlling the distribution of fish larvae in the NW Mediterranean. Prog. Oceanogr., 74: 355-376.

Somarakis, S. and E. Maraveya. - 2001. Covariation in mean abundance of larval myctophids and zooplankton biovolumes in the NE Aegean Sea. Rapp. Com. Inter. Mer. Médit., 36: 325.

Somarakis, S. and N. Nikolioudakis. - 2007. Oceanographic habitat, growth and mortality of larval anchovy (Engraulis encrasicolous) in the northern Aegean Sea (eastern Mediterranean). Mar. Biol., 152: 1143-1158.

Somarakis, S., B. Catalano and N. Tsimenides. - 1998. Catchability and retention of larval European anchovy, Engraulis encrasicolus, with bongo nets. Fish. Bull., 96: 917-925.

Somarakis, S., E. Maraveya and N. Tsimenides. - 2000. Multispecies ichthyoplankton associations in epipelagic species: Is there any intrinsic adaptive function? Belgian J. Zool., 130: 125-129.

Somarakis, S., P. Drakopoulos and V. Filippou. - 2002. Distribution and abundance of larval fishes in the northern Aegean Sea -eastern Mediterranean- in relation to early summer oceanographic conditions. J. Plankton Res., 24: 339-357.
Somarakis, S., D.E. Tsianis, A. Machias and K.I. Stergiou. - 2006. An overview of biological data related to anchovy and sardine stocks in Greek waters. In: M.L.D. Palomares, K.I. Stergiou, D. Pauly (eds.), Fishes in Databases and Ecosystems. Fisheries Centre Research Reports 14. Fisheries Centre, University of British Columbia, pp. 56-64.

Somarakis, S., A. Ramfos, A. Palialexis and V.D. Valavanis. - in press. Contrasting multispecies patterns in larval fish production trace inter-annual variability in oceanographic conditions over the N.E. Aegean Sea continental shelf (eastern Mediterranean). Hydrobiologia.

Stergiou, K.I., E.D. Christou, D. Georgopoulos, A. Zenetos and C. Souvermezoglou. - 1997. The Hellenic Seas: Physics, chemistry, biology and fisheries. Oceanogr. Mar. Biol. Ann. Rev., 35: 415-538.

Tsikliras, A.C., E.T. Koutrakis, G.K. Sylaios and A.A. Kallianiotis. -2009 . Summer distribution of fish larvae in northern Aegean Sea. J. Mar. Biol. Assoc. U.K., 89: 1137-1146.

Tsikliras, A.C., E. Antonopoulou and K.I. Stergiou. - 2010. Spawning period of Mediterranean marine fishes. Rev. Fish Biol. Fish., 20: 499-538.

Tzanatos, E., E. Dimitriou, G. Katselis, M. Georgiadis and C. Koutsikopoulos. - 2005. Composition, temporal dynamics and regional characteristics of small-scale fisheries in Greece. Fish Res., 73: 147-158.

Tzanatos, E., S. Somarakis, G. Tserpes and C. Koutsikopoulos. 2006. Identifying and classifying small-scale fisheries metiers in the Mediterranean: A case study in the Patraikos Gulf, Greece. Fish Res., 81: 158-168.

Scient. ed.: J.J. Govoni.

Received November 3, 2010. Accepted February 7, 2011.

Published online June 8, 2011. 